\title{
“Quo vadis”, Universidade encurralada, engessada e estagnada?!
}

http://dx.doi.org/10.11606/1807-55092017000nesp027

Jorge Olímpio BENTO*

Há coisas encerradas dentro dos muros que, se saíssem de repente para a rua e gritassem, encheriam o mundo.

Federico García Lorca, 1898-1936.

\section{Agradecimento}

Foi com uma sinfonia de alegria, gratidão, honraria e orgulho que recebi o convite para me associar à jubilosa celebraçáo dos exitosos 40 anos da pós-graduação na EEFE-USP. Tendo sido relegado para a prateleira da aposentadoria, com as ilaçóes decorrentes de tal estado, soube-me bem receber o convite. A memória e a saudade puseram-se a bater palmas às convicçóes.

Recordo a amizade e a familiaridade que, ao longo dos anos, usufruí na Escola, como uma graça recebida da generosidade da sua comunidade: professores, funcionários e estudantes. Seja-me permitido destacar três vultos de extraordinária valia, comprovadores de que as prestaçóes científicas e as virtudes humanas se frutificam mutuamente: Os Professores (sim, com letra maiúscula!) Alberto Amadio, Go Tani e Valdir Barbanti. Por favor,

\section{Propósito}

Move-me o intuito de passar em revista a universidade ${ }^{a}$. Apelo aos leitores para que me sigam com o espírito alumiado mais pela luz do dissenso e discordância do que pelo lusco-fusco do consenso e concordância, neste itinerário por dentro da alma mater. Pratiquemos, em conjunto, a pedagogia socrática, concedendo a primazia à argumentação, combinando a perspectiva individual e a predisposição para a prestação de contas, preferindo a crítica ao conformismo e o respeito à indiferença, e sabendo colocar-nos no lugar do outro. não levem a mal que os refira, quer pelo seu papel de percursores, quer devido à comunháo de afetos, bem como de projetos e visôes existenciais e institucionais que se estabeleceu, de forma espontânea, entre nós! Poderia nomear muitos mais, ciente de que os iniciadores de outrora têm excelentes continuadores agora. A todos envolvo com um apertado abraço, endereço exultantes felicitaçóes e presto sentida homenagem pelo pioneirismo e grandeza do empreendimento realizado, acreditador de justíssimos encómios, e prenunciador de um radioso porvir.

O convite para estas garatujas veio lembrar-me que a nossa convivência valeu a pena. Que há pessoas que fazem a diferença e conferem altura às coisas. $\mathrm{E}$ que os princípios e valores são imorredoiros. Bem hajam, muito queridos e fraternos Amigos!

haje 
para não desagradar aos chefes, o 'não-mecomprometo', o 'deixa-andar', o 'não-é-comigo', o fazde-conta, o encolher-de-ombros e o piscar-de-olhos, todo este receituário leva as instituições à ruína, por mais imperiais e sacrossantas que elas sejam.

Não é a rebeldia crítica a maior virtude do intelectual?! Sou académico; não contem comigo para a deserçáo cívica e para a cobardia intelectual. Descomprometido do exercício cívico, o intelecto não serve absolutamente para nada, encolhe e estiola completamente.

Temos a obrigação de arrostar a incomodidade e o risco de nomear aquilo que nos ameaça. Como disse Manuel Vasquez Montalbán (1939-2003), jornalista e poeta espanhol, "dar um nome ao que nos destrói ajuda-nos a defendermo-nos”.

Obviamente, as palavras não resolvem problemas, mas criam e avivam a consciência acerca deles. Fazem e irradiam a luz da revelação e são berço da procura de solução. Ora é de luz que tanto precisamos nesta hora crepuscular. Para tecer uma narrativa, suscetível de figurar ao lado de outras conjeturas possíveis, inclusive divergentes. Até porque a Verdade é nua; a sua apresentação pública desafia cada um a vesti-la com a roupa que lhe aprouver. Lembra José Saramago (1922-2010), "as verdades únicas não existem: as verdades são múltiplas. Só a mentira é global.”

As opiniôes, proclamou John Stuart Mill (18061873) no livro intitulado On Liberty (Sobre a Liberdade), são valioso património da humanidade. Silenciar uma opiniáo equivale a um roubo: se estiver certa, perdemos uma oportunidade de corrigir o nosso ponto de vista; se estiver errada, perdemos uma oportunidade de rebater a sua falsidade.

Depreende-se da minha linguagem que não enfileiro na lista dos falantes da 'novilingua' adotada, oficial ou oficiosamente, nos meandros universitários. A justificação foi descrita de maneira magistral pela perspicácia de George Orwell (1903-1950): A 'novilingua' é o linguajar ideal do Estado controlador, vigilante, punitivo, liberticida e 'libertador' da permissividade. A sua missão é liquidar a 'velha lingua', com o objetivo único de estreitar o alcance e o espaço do pensamento.

Este intento tem sido consumado nas últimas décadas, diminuindo todos os anos o número de palavras. Com a diminuição das palavras em circulaçáo, reduz-se concomitantemente a amplitude e acuidade da consciência, eliminam-se os conceitos que permitem apreciar os delitos da imaginação e ação. Enfim, através da aniquilaçáo do vocabulário, condiciona-se e elimina-se a noção de 'liberdade'.

Sublinhe-se este 'pormenor', por ser 'pormaior': a 'novilíngua', que circula por aí de crista levantada, ostensiva e pomposa, não surgiu por acaso, espontaneamente e sem finalidades devidamente ponderadas. $\mathrm{O}$ jargão vocabular corrente é intencionalmente preguiçoso, para servir propósitos ideológicos. A restrição e padronização da terminologia em curso não anulam apenas as diferenças e a variedade dos modos de dizer; empobrecem igualmente a capacidade de conceptualizar e ver.

Mais, a 'novilíngua' em vigor (competitividade, empreendedorismo, rankings, sucesso e pérolas afins) é metáfora da pilhagem violenta de sonhos aos ingénuos. Estes são guindados a um universo mirabolante que lhes é estranho, não compreendem, mas do qual sofrem a pressão; tornam-se joguetes acossados e possuídos por forças que os disputam e inebriam com o delírio da ambição e vaidade. Com ela institui-se uma nova forma de ocultar e velar o jogo, de poder e de controlo psicológico e sóciopolítico das mentes: os seus utentes controlam-se a si próprios, não carecendo de controlo externo ${ }^{c}$.

$\mathrm{O}$ afunilamento da linguagem acarreta, pois, o tolhimento da idealização, da compreensão, da visão, da expressão e, consequentemente, da competência de valorar e optar. O léxico é a porta de acesso ao nosso mundo interior, a tudo quanto o agita e povoa; e a chave de decifraçáo dos códigos do mundo exterior, do Outro, dos factos, fenómenos e coisas.

Em suma, o nosso vocabulário é um 'artefacto'. Porém não se restringe ao papel de castiçal numa mesa de jantar. É, sobretudo, um 'artifice': comporta a 'arte' de saber ler o cardápio, de fazer a escolha e encomenda do que preferimos comer.

Advirto ainda os leitores de que os meus arrazoados são ditados pela observação do que acontece na universidade portuguesa, especificamente naquela a que pertenço. Todavia, conheço o bastante para me aperceber de que os males indígenas repercutem insanidades com maiores ou menores ramificaçóes à escala universal. Poderá haver ligeiras variaçôes na aparência; a origem e a pauta musical são as mesmas. 


\section{Da 'parrésia' ou coragem da verdade}

Neste exame ou sobrevoo da universidade serveme de bússola a 'parrésia' ou 'coragem da verdade'. Considerada pelos filósofos pré-socráticos e por Sócrates (469/470-399 a. C.) a mais excelsa virtude, a coragem flamejante de buscar, afirmar e defender a verdade é expressa por proclamaçóes e tomadas de posição, fundadas na experiência crítica da história, da realidade e da vida. Perfaz o genuíno metropadrão do Ser Humano, porquanto este pressupóe o requisito de ser crítico, interrogativo e racional, de transpor fronteiras ideológicas, de abandonar preconceitos e juízos definitivos e fechados, de denunciar e recusar falsificaçóes e manipulaçóes, de abater obstinaçóes doutrinárias absurdas. Eis aqui o sentido e a finalidade do testemunho exarado nestas páginas!

Desde o berço e a escola primária na aldeia transmontana, até à jubilação da cátedra na Universidade do Porto, fiz a viagem com o substancial que os meus pais me ensinaram e transformaram em modo de agir: o arreigado apego à verdade, imaginada e falada. À medida que fazia a viagem, mais ficava contaminado pelo vício da palavra desassombrada e desempoeirada, sem grilhetas e sem verniz, a não ser o da ética e estética.

E não me dei mal, mesmo tendo feito inimizades, certamente dispensáveis, mas também 'convenientes'; elas atestam que a medida do agravo causado e pressentido também o é de algum mérito agregado e atingido. Devo este à nunca atropelada intençáo de distanciação:

- Dos dogmas e estereótipos do 'politicamente correto', da postura impositiva e fascizante do pensamento único, em que é sacrilégio questionar;

- Das hipersimplificaçóes que limitam a lucidez e a abordagem inteligente dos problemas, e se contentam em ver algumas árvores, sem compreender a floresta.

Esta preocupaçáo recebeu o sal do conselho de Agostinho da Silva (1906-1194): "Procura, diante dos acontecimentos, ter as tuas reaçóes, não as dos outros ${ }^{1 .}$."

Mas...porque trago semelhante coisa à colação? Porque a universidade é, matricialmente, a acrópole do discutível e não o templo do indiscutível, a morada natural da 'parrésia'. Esta é trave-mestra do edifício universitário, por constituir uma disposição básica da inteligência, uma conaturalidade e propensão espiritual e volitiva, um permanente estado de alma e de prontidão para a afirmação e negação. Uma atitude de modéstia subversiva, de atalaia e vigilância contra cânones de toda a índole, convidativos ao acomodamento e descaso, à indolência, letargia e preguiça, e à substituição da essencialidade pela superficialidade.

A atitude crítica é imperativo moral de todo o ente humano que não suspenda o interesse pelo mundo e queira estar à altura das exigências e circunstâncias da vida. Quanto a um docente universitário, nem se fala! Porém, ela engrossa a extensa lista de refugiados desta era; é escorraçada de toda a parte, inclusive da universidade, como se fosse um cão tinhoso. Por este andar, aonde irá parar? Sei, e não me conformo, o tipo de indivíduo que estamos a fabricar: foge da 'parrésia' como o diabo da cruz! É um medíocre, incapaz de qualquer compromisso com causas e ideais.

A 'coragem da verdade' alimenta-se do ceticismo e pessimismo, inimigos da resignação e prenhes de ironia e apetência para a intervenção. 'Chateia-se' solenemente, protesta em voz alta e em escrita afiada, indigna-se e náo faz cedência a uma universidade encaixilhada em alumínio; reclama molduras e materiais mais nobres. Porém, não se ilude! Pela aragem, percebe que os mestres-de-obra não empreenderão outro modelo de construção. Contudo, não renuncia ao caminho moral.

Se alguma vez nos faltar o destemor suficiente para enfrentar as potestades e os ventos do mal, retiremos encorajamento da atitude do Prémio Nobel de Literatura Camilo José Cela (1916-2002), dirigindo-se a um governante, numa sessão pública: "Señor ministro, no se ofenda si le llamo imbécil, pues esto no es un insulto, es un diagnóstico."

Usemos o 'náo' como arado da dignificação e remissão da nossa conduta, tal como propóe a poetisa Ana Luísa Amaral: "Dizer 'não', repeti-lo muitas vezes, insistir a indignação, tornar o 'não' em som cada vez mais aberto, alongar-lhe o sentido, denunciar estas vergonhas e estas brutalidades. E reclamar paz. Não a paz do repouso, mas a paz da justiça social e da cessação da guerra que é a violência sobre todo um povo. Lembrar que o 'não', esta pequena palavra, usada todos os dias, pode habitar um lugar novo de sentido. E que sendo, no dizer poético e em metáfora, a mais selvagem, pode também ser, na vida, a única suficientemente poderosa para combater a selvajaria. E contra ela arder, acesa ${ }^{2}$." 


\section{Como vejo a universidade}

Todas as épocas são eras de 'crise', segundo o lídimo significado deste termo. Tudo muda, nada fica como está! A universidade não escapa a esta circunstância: é uma instituição semper reformanda, sempre à procura de uma forma nova, superior, mais perfeita e apta a responder aos anseios da Humanidade.

Porém, a 'crise' desta hora apresenta contornos diferentes do pressuposto anunciado. Ela parece trazer o demo no ventre. Com efeito, a universidade anda à deriva, perdeu o rumo, agitada por ventos estranhos à sua matriz. Hipotecou a autonomia e independência; tornou-se refém de poderes que a controlam e lhe ditam os passos; e aos quais se conforma de maneira servil, transformando-se, inclusive, em caixa-de-ressonância e de propagação da ideologia e do senso comum reinantes. Encontrase em nítida perda de identidade.

E o que faz a comunidade académica? A maioria suporta e reforça a involução com a sua conduta, seja esta de conivência ativa, seja de omissão e renúncia à tomada de posiçáo, seja ainda de total ausência de percepção ou de inconsciência em relação à agenda perversiva. De um modo ou de outro, a cumplicidade com a caminhada para o abismo é o distintivo comportamental de um grande número de académicos. Quando não aplaudem, enfiam a cabeça na areia como a avestruz, fingem-se de distraídos e assistem a tudo, indiferentes aos efeitos de erosão da missão e relevância social da instituição. Talvez cuidem que a erosão não os atinge, mas não perdem pela demora; a atual Via Crucis da universidade configura, simultaneamente, o caminho para a

\section{Perguntas incontornáveis}

Hoje na universidade (escrita cada vez em letra mais pequena!) reina um silêncio de morte. Urge ressuscitar o verbo e pôr as bocas e gargantas a nomear e questionar. Há perguntas incontornáveis, que aguardam respostas inequívocas:

- De que janela e com que luz quer a universidade aguardar a vinda do futuro? Com que tipo de futuro deseja ter cumplicidade? ("Nem todos os futuros são para desejar, porque há muitos futuros para temer", advertiu o Padre António Vieira,1608-1697)³. irrelevância dos docentes, para o naufrágio e para a proletarizaçáo do seu estatuto sócio-cultural e económico. Não assumem a responsabilidade por eles, nem pelo legado que deixam aos vindouros: uma instituição enfraquecida e salários minguados, conformes às maquinaçôes dos mandarins desta era de regressão civilizacional. Sem receber nada em troca!

Como reza o ditado, "Roma não paga a traidores". Também o império neoliberal não paga a cobardia e a traição, que vigoram na universidade, desde o topo até à base da pirâmided .

Infelizmente, este lucubrar equivale a deitar pedras em saco roto. A universidade é farta em personagens afeitos à posição de cócoras; só se erguem para espreitar por todas as 'janelas de oportunidade'. O brilho da novilíngua da 'doce barbárie' (Jean-Pierre Le Goff) cega-os e torna-os ansiosos por colher os ganhos da competitividade, receber os dividendos do empreendedorismo, morar no gigantesco condomínio (ou será sarcófago?!) da massa crítica (como se o espírito crítico despontasse da 'massa'), ter o nome inscrito nos 'rankings', etc.

Permanece atual (e direcionada para muitos figurantes no palco universitário) a síntese fulminante de Almada Negreiros (1893-1970), no Manifesto Anti-Dantas: "Dantas é um habilidoso e um ciganáo, (...) um pantomineiro. Para ter chegado aonde chegou basta não ter escrúpulos, nem morais, nem artísticos, nem humanos. Basta usar o tal sorrisinho, basta ser muito delicado (...) e ter olhos meigos (...) Basta ser Judas. Basta ser Dantas."
- Quer ser instituição de 'formação' ("Bildung") ou oficina de formatação e instruçáo 'funcionalizante', domicílio da erudição, da espiritualidade, do intelecto, da cultura e da sabedoria ou palanque de amplificação do 'mainstream' ideológico?

- A sua nova e exaltante missão e vocação é ser uma 'fábrica de papers'?! É esta a sua realização cimeira, e autónoma das outras?

- Sendo a investigaçáo fundamental, livre e sistemática, indispensável para o avanço da ciência 
em todos os domínios, e para o bem-viver dos povos, como valoriza a universidade aquela exigência e se distancia das linhas de pesquisa impostas por modas e pressóes das redes do império editorial?

- Pressente-se nela disponibilidade para a autointerrogação se estará ou não, com a deriva pragmática e reverenciadora do putativo mercado, a cometer suicídio e genocídio (epistemecídio) científico e intelectual?

Agudizemos o modo e o sentido do perguntar. Perante quem e o quê somos universidade e académicos? Pergunta simples; experimentemos fazê-la, pensá-la e responder-lhe!

$\mathrm{Na}$ conjetura da resposta encontraremos a história de cada um de nós, a da universidade e a da Humanidade (de Caim e Abel, de Dalila e Sansão, de Brutus e Júlio César, de Judas e Jesus). A resposta póe à mostra: traição, deslealdade e oportunismo, que se alimentam da inveja e cobiça. E revela à saciedade duas mazelas à rédea solta no campus universitário:

- O traído (causa ou pessoa), sempre está e estará à frente e acima do traidor. Este não recebe paga, a não ser quando a traição muda de nome e se chama 'pragmatismo'.

- A deslealdade é anónima e manhosa; não raras vezes, chama-se 'oportunismo', colhe encómios e louvores, anda sempre à superfície como uma rolha de cortiça, malgrado as águas revoltas.

Muitos triunfadores do momento náo se apercebem da derrota que carregam às costas, como se fossem uma tartaruga. Mais cedo do que tarde, confirmar-se-á o veredicto de Victor Hugo (18021885): "A traição trai o traidor." $\mathrm{E}$, igualmente, o de Santo Agostinho (354-430): " Os mentirosos são inimigos de si mesmos."

\section{Cenário sombrio}

Como o título sugere, a estória não é de encantar. Integra-se no ambiente de cinismo que se apoderou da política, em geral, e da ambiência universitária, em particular, na última dúzia de anos. Não é só cinismo; abundam cenas chocantes, de farsa, mentira e tragédia. Por isso, aconselho os leitores mais sensíveis a parar aqui e não prosseguir na leitura.

A explanação pode conter alguma falha nos pormenores, como é próprio das estórias; mas não falta à verdade no relato do essencial, nem se enreda
Sim, disse-o Vergílio Ferreira (1916-1997): “O pensamento que não age é uma traição." Não há desculpa para ela. O imperador romano Marco Aurélio (121-181) é taxativo: "Não se é menos culpado não fazendo o que se deve fazer do que fazendo o que não se deve fazer." Ou seja, mesmo sendo cometida por negligência, por incúria, ingenuidade, imperícia e irresponsabilidade, a traição tem um efeito devastador: esvazia o traidor da essência do Ser, anula-o como pessoa, atenta contra o que ele acredita ser.

Acrescentemos ainda uma pitada ao amargo molho da traição. A leitura do último (Os três reis do Oriente) dos Contos Exemplares, de Sophia de Mello Breyner Andresen (1819-2004), alerta-nos para as decepçóes "com as consultas aos homens das ciências".

O rei Baltasar, frustrado de procurar em vão, pediu aos doutores da religião: "Dizei-me onde está o altar do deus que proteja os humilhados e os oprimidos, para que eu o implore e adore." A resposta foi nua e crua: "Desse deus nada sabemos."

Náo têm nada a ver com isso e com um mundo melhor a universidade, os seus dirigentes e membros?! Não, dolorosa e infelizmente não têm: a universidade omite-se, abdica de falar e tomar partido entre o bem e o mal, perde prestígio, protagonismo e respeitabilidade; deixa-se 'encurralar' (no sentido literal do termo!).

Encontramo-nos num momento que nos coloca desafios cruciais, expressos por Cornelius Castoriadis (1922-1997) deste jeito: "É preciso escolher: ou descansamos ou somos livres."

A cobardia moral traça o destino do mundo e também o da universidade. Esta anda numa dança de fogos-fátuos, que confunde com o arco-íris. Quer manter o fogo do espírito, mas falta-lhe e deita fora a lenha para fazer essa fogueira.

em juízos de intençôes. É fácil conferir: a realidade não mente, persiste no presente e lança pontes de ruína para o futuro.

Era uma vez... no tempo da famosa 'terceira via', propalada como maravilha 'reformista', para encobrir a sordidez do casamento, em comunhão de bens, com o ultraliberalismo. Os agentes e serventuários do economês e financês tomaram o poder e passaram a implementar políticas e medidas de austeridade, atentatórias e sacrificiais dos legítimos anseios e 
direitos dos cidadáos, camufladas de imperiosas e benfazejas 'reformas estruturais'.

O 'experimentalismo' irrompeu em todos os setores, prometendo trazer de volta o paraíso terrestre. No campo da educação, a operação começou com os docentes do ensino básico e secundário. Estava na cara quem seria o próximo alvo! Mas, como no poema de Brecht, os do ensino superior acharam que não era nada com eles; e deixaram que a Caixa de Pandora se abrisse cada vez mais, 'libertando' os ventos do mal. Os laureados sábios e sabidos, não contentes com o impacto do golpe desferido pelo Processo de Bolonha na universidade, decidiram transformar esta em empresa, submetê-la aos ditames do 'managerialismo', e convertê-la numa fronda do mercado e do mundo dos negócios.

Para tanto fabricaram a famigerada lei 62/2007, de 10 de setembro, vulgarmente conhecida como RJIES-Regime Jurídico das Instituiçóes do Ensino Superior ${ }^{\text {e }}$ Com ela assestaram várias cajadadas: liquidaram a democracia na universidade, introduziram nesta forças externas, manifestas ou ocultas, e entregaram-lhes o mando. Não era ainda suficiente! Impuseram o credo da tresloucada 'competitividade' e de outras cegueiras afins, e uma burocracia asfixiante e opressora das pessoas, tirando-lhes espaço para se aperceberem do laço que estava sendo tecido à volta do seu pescoço.

Como sói acontecer em casos idênticos, os bispos do 'reformismo' cuidaram de engrossar as fileiras e de arranjar ajudantes da missa, recrutando fiéis (vários com nome sonante), alocados em laboratórios associados, gratificados com apoios substanciais. De modo que no coro da denúncia e resiliência alinhavam poucas vozes, facilmente abafadas. Até porque no palco mediático uma orquestra, bem afinada, tocava loas à 'inovaçâa' e aos seus generais, sargentos e cabos-de-ordem.

Deste jeito, o cortejo prosseguiu a marcha triunfante, com vestes festivas e sob um pálio protector de quaisquer raios solares, com a turba multa prostrada à sua passagem, de joelhos em terra e de cabeça inclinada para o chão, em atitude de vassalagem e veneração, para não ser tentada pelo mínimo impulso de curiosidade e contestaçáo.

$\mathrm{O}$ orçamento das universidades, que já era escasso, foi drasticamente reduzido, ficando muito aquém do necessário para pagar os salários dos docentes e funcionários. Mas não havia mal algum nisso, proclamavam os cruzados do 'aggiornamento neolibelês' da alma mater! Esta podia gerar receitas próprias na ordem de $50 \%$ dos fundos necessários para cobrir o seu funcionamento! A sério?! Sem a menor dúvida, a adesão ao estatuto de fundação daria uma significativa ajuda nesse sentido! Para não falar no infalível milagre do 'empreendedorismo'. Em todo o lado e a toda a hora, os altifalantes difundiam o discurso tonitruantef.

Vai daí, as faculdades viram-se forçadas à conversão em fábricas de cursos para tudo e para nada, ao agrado do paladar do freguês, uns mais longos, outros curtos, de todas as formas e feitios e com diversas finalidades, inclusive para cortar o cabelo e as cunhas, para coçar as costas, para matar pulgas e piolhos, para atar os cordóes dos sapatos, durante o período letivo e nas férias, de dia e à noite, durante a semana e no fim desta, etc. Não havia outra soluçáo. Era preciso obter dinheiro, a todo o custo, para garantir a sobrevivência; e para que Suas Excelências vissem confirmada a assertividade das posiçóes dogmáticas, pregadas do alto dos seus púlpitos sagrados.

Porém, para manter tanto curso e cursilho em funcionamento, os docentes do quadro não bastavam. E para que o dinheiro proveniente do Orçamento de Estado e do orçamento privativo chegasse, era imperioso conter as despesas. Nada que não pudesse ser obviado; para todos os empecilhos foram inventadas soluçóes e criadas regulamentaçóes. A progressão nas carreiras foi congelada e recorreu-se à contratação de jovens docentes, com vencimento a tempo parcial, embora muitos deles dedicados exclusivamente à instituição. Alguns foram mesmo contratados a $0 \%$ ! Tudo legal, à luz das normas em vigor na caserna! Ademais, essa gentalha podia ser removida todos os anos: portanto tinha que comer e calar o que lhe punham à frente!

Não faltaram figuras proeminentes a advogar a redução drástica das aulas presenciais, bem como o recurso a estudantes de doutoramento para assegurar a lecionação. A recomendação foi auspiciosamente recebida por muita gente, uns porque dar aulas é uma maçada, outros porque tinham mais que fazer, além de que lecionar bem ou mal tanto faz para vencer concursos de avanço na carreira.

Como assim?! Os fins justificam os meios; logo, tudo valia e tinha que ser rentabilizado, e todos os processos, inclusive a prática da escravatura, serviam para cumprir o cavernícola projeto do economicismo ideológico.

Mas...então a comunidade académica assistiu a isto de braços cruzados?! Sim, a maioria assistiu; não faltou quem a alertasse para a periculosidade da insana deriva, e apelasse à sua mobilização 
contra a ratoeira em que tinha caído. Contudo, ela, por um lado, reclama-se 'apolitica', entende que mobilizaçóes e tomadas de posição de teor político são reaçôes típicas da populaça, mancham a sua reputação pseudointelectual, e lançam os seus parentes na lama. Por outro, cuida que, para problemas de índole político-ideológica, há soluçōes técnicas. Santa crendice e ingenuidade! Ou será antes estultice, covardia, conivência e irresponsabilidade?!

E hoje, José, para onde sopram os ventos? O clima mantém-se e tende a agravar-se. Os professores associados e auxiliares, cansados do estacionamento no posto, almejam ascender aos lugares superiores dos quadros, por preencher. Para tanto é preciso calcular bem a massa salarial, dada a sua magreza. Há ou não solução para satisfazer tão legítima aspiração? Há, sim: despedir os docentes jovens! Só que, atirados estes para o caixote do lixo, é impossível oferecer os cursos que são fonte da receita; e, sem esta, também não é viável aquela ascensão.

Que contrariedade e maçada! O milagre da conversão da água em vinho e da multiplicação do páo e dos peixes é obra da imaginaçáo humana para exaltação da capacidade de criação divina; mas não está ao alcance do regime fundacional, por mais pozinhos mágicos que os fantasistas lhe ponham em cima!

A situação caminha, a passos largos, em direção à calamidade. $\mathrm{O}$ envelhecimento do corpo de docentes e funcionários acentua-se, a olhos vistos. Ao panorama de catástrofe iminente assistem impávidos os reitores nomeados pelo Conselho Geral, órgão saído das entranhas satânicas do RJIES. Os Presidentes e não poucos conselheiros vindos de fora assemelham-se aos comentadores e treinadores de futebol feitos a martelo. Não entendem nada da universidade; diga-se, em abono da verdade, o órgão também não foi criado para servir a instituição, mas para a subjugar a interesses espúrios. Todavia, usam a função como um penacho de ornamento da sua fachada pública, igual a índios na orla da floresta. Graças a Deus, as universidades enfrentam dificuldades para o exercício da sua atividade, mas não para suportar o doutíssimo, iluminadíssimo e utilíssimo Conselho Geral!?.

Será preciso carregar mais nas tintas para mostrar a feiura do cenário? Tudo sugere que sim; alguns só acordam mesmo, quando lhes são espetados pregos nos olhos!

\section{Problema preocupante: 'funcionalização dos docentes'}

A universidade tem vindo, nos últimos anos, a ser configurada como uma 'máquina de triturar intelectuais'. Ela caiu sob a alçada de uma estrutura ideológica que 'funcionaliza' os intelectuais ou, em obediência ao rigor, promove a produção em série do 'intelectual funcionalizado'.

Os docentes estão despindo o hábito de intelectuais. A sua atividade tem vindo a deteriorarse, a perder liberdade académica e dimensão crítica.

A retórica universitária passou a ser inundada pelo credo da eficiência e dos 'outputs', por pressóes para a adopção de metodologias de gestão mais próximas das empresariais $s^{\mathrm{h}}$.

O mesmo é dizer, o espaço académico sofreu uma metamorfose epidémica. Nele impera uma sobrecarga de rotinas que convida os docentes a descurar o aprimoramento cultural, espiritual e intelectual da sua personalidade, o ócio criativo e a dimensão da vida afetiva e familiar, revertendo isto em desfavor e deslustre do desempenho cabal e nobilitante da sua missão.

A atividade dos docentes, além de burocratizada, alienada e esterilizada pela competição infrene, é pobre de alcance axiológico e formativo. A pressão obrigacionista e obsessiva das avaliações, dos "rankings", das metas e dos objetivos, de 'fazer curriculum' e mostrar resultados evidentes, palpáveis e quantificáveis para prestar provas, de depreciar e desqualificar tudo o que não se ajusta ao figurino estatístico, gráfico e numérico - toda esta doidice afunda, deteriora, esmaga, oprime e transforma radicalmente o desempenho, o desígnio e a essência da docência.

A entrega à instituição e aos estudantes, o ensino e a sala de aulas são olhados como parentes pobres, coitados, tolheitos e portadores de toxicidade, em vias de ser riscados da lista de convidados para a festa da contabilização.

Assuma-se, sem sofismas ou subterfúgios, a perversão: 'Ensinar' e 'Educar' - e a extensão das suas implicações - não são termos benquistos no dourado dicionário perfilhado no areópago universitário nos dias de hoje!

Sim, as mudanças são inquietantes. Porém, a maioria dos docentes universitários não parece sentir-se incomodada com o rumo da universidade, nem com o modo como exerce o seu labor 
académico. Abdicaram do estatuto e obrigação de ser intelectuais e de pensar o mundo, a sociedade, a instituição e a si próprios. Recusam-se a assumir a responsabilidade de intermediários entre as ideias e a cidade, de agentes do despertar e esclarecer a consciência coletiva, de dizer e propor o possível e desejável sobre o seu tempo e as suas circunstâncias.

A profissão docente (a bela e nobre profissão de formar pessoas) está doente. E muitos dos seus agentes não o estão menos. Estão naturalizados num papel e afundados numa irracionalidade que, eles sabem isso perfeitamente, origina um ambiente de exaustão física e psicológica.

\section{“Quo vadis”, universidade?!}

Para onde vai a universidade? Para onde está sendo empurrada? Qual é o 'ideal' ou, antes, a demência que a guia? Às ordens e no interesse de quem estáo a ser descartados o conceito e a missão tradicionais?
Debaixo do tapete da desculpa para o cumprimento das imposiçóes, escondem-se a mediocridade e a falta de criatividade e de ousadia para reagir a uma situaçáo degradante.

A função do docente universitário já não é o que era, afasta-se a passos largos do imaginário que a edificou e habitava. $O$ grau da decadência foi proclamado por Hegel (1770-1831): "Naquilo com que um espírito se satisfaz, mede-se a grandeza de sua perda".

Esta é enorme e medonha; no entanto, é escasso o número dos académicos que se erguem contra semelhante calamidade.

As interrogaçôes equivalem a constataçôes e inquietaçôes. A universidade já viveu dias melhores e percorreu caminhos mais afortunados. As risadas, que se ouvem, não são de alegria, nem de quem lhe quer bem.

\section{Primeiro: dos muros entre o inseparável}

Os grandes vultos da ciência, que nos habituamos a admirar, embora vinculados a uma área do saber, transitam por outras áreas ou são contíguos a elas, procurando relacionar o particular com o geral, o local com o universal, o minudente com o abrangente. Situados no seu tempo e na sua courela disciplinar, não se deixam sitiar nem pelo primeiro, nem pela segunda; antes, primam pelo esforço de transpor a muralha disciplinar e transcender as circunstâncias.

Esses cientistas são pensadores e sábios, sensíveis a todas as modalidades de exaltação e laboraçáo do Humano. Não se distinguem tanto pela posse do saber enciclopédico, mas sobretudo pela abertura à vastidão de fontes de conhecimento, criação e reflexão, pelo seu carreamento e manuseio na iluminação do respetivo quotidiano. Muitos deles convivem intensamente com as artes e letras e delas colhem proveitos, porquanto a capacidade de ficcionar (de inventar e contar histórias, e de com elas encantar) estende-se a todas as outras formas de idealizar e raciocinar, fecundando-as e puxando-as para as alturas. Afinal, lembra Lídia Jorge, "a ficção é o lugar mais próspero do nosso espírito (...) A História, a Filosofia e a Ética são filhas diretas da ficção. São as suas prefigurações maiores”‘ (p.11).

Tais vultos abundam na Modernidade, no Humanismo e Iluminismo. Mas também os conhecemos na contemporaneidade, nomeadamente na universidade hodierna. Todavia, esta afastou-se nitidamente daquele caminho. O ideal do indivíduo experimentado, maduro e de saber ampliado (postulado por Homero, Kant, Luc Férry e tantos outros), possuidor de um património de narrativa suscetível de entusiasmar e maravilhar os outros, vê-se derrubado pela bitola estreita do sujeito de conhecimento especializado, mirrado e seco. Os sábios à maneira de antanho são agora uma espécie em vias de extinção. $\mathrm{O}$ pensamento não parece andar de mãos dadas com a ação. Pasme-se, em muitos casos erguem-se muralhas inacessíveis entre a sabedoria e a investigação! Esta abeira-se do calcular e afasta-se do pensar. 


\section{Segundo: carência de 'formação', pensamento e 'contemplação'}

Afirmo e sustento, mais uma vez em nome da 'parrésia': a universidade está a ficar obesa de 'instrução funcional', e escanzelada e seca de 'Formação' ("Bildung”) e pensamento. E assiste, de braços cruzados, à vitória dos mecanismos destruidores da sua idiossincrasia.

A noção de 'Formação', que tomo como referência, é a estabelecida pelo Barão Wilhelm von Humboldt (1767-1835). A ele deve-se a fundação da Universidade de Berlim e a estruturação conceptual da universidade na era moderna.

O teor da 'Formaçâo' pode ser igualmente concebido à luz da conhecida proposição de Platão (428/427-348/347 a.C.): "O que faz andar o barco não é a vela enfunada, mas o vento que não se vê.”

Que ventos sopram hoje na universidade? Têm algo a ver com os que se evadiram da Caixa de Pandora? Há alguma inquietude em relação à possibilidade de correlação?

Poderá a mestria técnica e instrumental, sem mais nada, converter uma pessoa má num 'excelente' profissional?

A formação subentende a competência para a 'compreensão' e o 'entendimento', à luz do entendimento de Miguel Torga (1907-1995): "Compreender não é procurar no que nos é estranho a nossa projecção ou a projecção dos nossos desejos. É explicar o que se nos opóe, valorizar o que até aí não tinha valor dentro de nós. $\mathrm{O}$ diverso, o inesperado, o antagónico, é que são a pedra de toque dum acto de entendimento ${ }^{5}$."

É a formação - e não a 'instrução funcionalizante' em alta e aceite pelo figurino da moda - que possibilita:

- Questionar o que deve ser questionado, alargar o olhar, enxergar e visar o distante, almejar a amplitude, a diversificação e a imensidão do espaço;

- Perceber o perdurável, o intangível, o simbólico, o não revelado, os "a priori" iluminadores e avaliadores dos "a posteriori";

- Atribuir significados, deixar-se atrair pela admiração e cultivo do belo e bom, da amabilidade, amenidade e convivialidade, da suavidade e moderação, da empatia, simpatia, compaixão, partilha e identificação com o outro, com o seu lugar e vivência.

Sim, a isto chama-se 'formaçâo':

- A aspiração de verdade que não consente o mentir, associa meios e fins, valora as ações humanas e as respetivas consequências, encoraja a escolher as boas e rejeitar as más!

- O que confere 'amplidão ao Ser' e caracteriza o Homem de 'saber ampliado', experimentado e multiplicado.

- O Ser propenso a 'compreender' e entender, a explicar e integrar o que se lhe opóe.

A 'formação' pressupóe pensamento e 'contemplação': concentração, cultura, demora, meditação, estudo e leitura, recolhimento, reflexão, serenidade e silêncio. Sem estes elementos, a vida enreda-se num 'acionismo' estapafúrdio e numa 'hiperatividade letal, semelhantes ao rabo cortado de uma lagartixa que no seu agitar se esgota. Os indivíduos afogam-se e esfalfam-se nos assuntos particulares, descambando para o desvão do 'imbecil especializado' (Ortega y Gasset).

É mortífero o desdém da necessidade de contemplaçáo: o olhar vagueia errante, incapaz de expressar algo da ordem do espanto. Sem o ingrediente da contemplação, "toda a vida humana terminaria numa hiperatividade fatídica" 6 .

É isto que está a acontecer, tal como anotou Nietzsche (1844-1900): "A falta de serenidade conduz a nossa civilização a uma nova barbárie (...) Uma das correçóes que urge, pois, fazer ao caráter da humanidade é desenvolver, e em grande medida, o seu lado contemplativo"7.

Os pensadores sempre foram uma raridade preciosa e cara. Nesta hora escasseiam ainda mais, devido ao facto da vita contemplativa ser "marginalizada em benefício da vita activa e de a inquietação hiperativa, a agitação e o desassossego atuais não se casarem bem com o pensamento". Este, "em consequência de uma pressão temporal cada vez maior, tende a náo fazer mais do que reproduzir o mesmo."

Nesta conjuntura náo é o pensamento que rege o tempo. É este que dita e comanda o pensamento, reduzindo-o a cálculo, e tornando-o efémero, frágil, volátil, sem contacto com o sólido e o duradoiro. $\mathrm{O}$ 'pensar apressado', emotivo e reativo, rouba o cetro ao 'pensar devagar', fundado na ponderação de informaçóes e opinióes, de alternativas e efeitos, na reflexão demorada e cuidada da tomada de decisóes.

$\mathrm{O}$ alarido e o espalhafato frenéticos e generalizados e a falta de tempo e tranquilidade para pensar acarretam a repulsa e o ódio pelas posiçôes divergentes, inviabilizam o aprofundar do pensamento, que este sobrepuje a realidade, a 
influencie com algo genuinamente diferente, novo e 'outro'.

O estendal de perdas é longo e de preço incalculável, pondo a descoberto o vasto rol de insanidades e malefícios consignados ao 'erro do sucesso' e à 'civilização desorientada' e tão necessitada de um novo humanismoi.

Não se iluda a realidade, o pensamento, os pensadores e filósofos são hoje cidadãos de segunda ou terceira classe na Pólis universitária. São malquistos e vistos como fardo incómodo e nefasto para a saúde e eficiência da locomotiva que puxa os inúmeros vagóes do trem de um produtivismo sem finalidade para além dele.

Será exagerada esta apreciação? Como disse, há excepções públicas e notórias; aqui e ali, nas faculdades e nos centros de investigação persistem exemplos de casamento feliz e inspirador entre a investigação e as outras formas exaltantes da imaginação e criação humana. Porém, surgem contra a corrente, à margem das modas e práticas enaltecidas e premiadas.

No entanto é irrecusável - e ninguém a nega! - a importância da reflexão filosófica para a formaçáo e investigação; não para acelerar e aumentar a produção das respostas, mas para fomentar e iluminar a procura e a pluralidade de novos e possíveis caminhos. Nesta era, em que os motores do carro do mundo (ciência, economia, tecnologia e política), alertam Edgar Morin e tantos outros, estão severamente danificados?

\section{Terceiro: da estagnação}

Assiste, pois, razão às chamadas de atenção para o facto de que a universidade se encontra estagnada e transformada em trituradora da intelectualidade. As práticas de engessamento e a falta de circulação das ideias são evidentes. Há demasiada presunção e vanidade e pouco desassossego. Muita gente enclausurada na teia das certezas aparentes e poucas pessoas abertas à inquietude, à metafísica e ao mistério de tudo. Só que o Ser Humano prende-se com a noção de que pouco ou nada sabe, com a consciência da incompletude e finitude, da inultrapassável imperfeição. Ora não é isto que hoje predomina na instituiçấo universitária.

Sem dúvida, os avanços e ganhos são assinaláveis no domínio do conhecimento empírico das 'coisas' naturais. Ocasionando contentamento justificado, e também deslumbramento que devia ser temperado e sublimado. Olvida-se que só o natural é possível
Mais ainda, a universidade não passa no exame da demonstração prática da sua capacidade e disponibilidade para apoiar, fundar e proclamar as respostas às grandes perguntas do nosso tempo. Eis o pensamento mutilado, favorecedor do aumento da angústia! E igualmente a prova da cobarde recusa da universidade em assumir responsabilidades por este nosso mundo, embora esteja nele diluída, imersa no senso-comum, a caminho de perder a sua identidade.

Como se isso não bastasse, a universidade está contaminada pela lógica managerialista, como os outros setores, inclusive escolas e hospitais. Mas uma universidade não é uma empresa! A sua lógica não é a do lucro, nem tampouco a do equilíbrio orçamentário. É outra! E também não é a do credo e dogma da avaliação e dos "rankings", impositivos de um jeito de calcular que ignora a complexidade e diversidade das realidades humanas.

É neste ponto que estamos encalhados. Como diz Edgar Morin, "o que não se regenera, degenera"10. O progresso náo é um dado adquirido e garantido para todo o sempre, seja em que plano for. As forças da degenerescência levam a palma às forças da regeneração. Não há muita gente a sentir a necessidade desta e a alistar-se nas suas fileiras. Bem pelo contrário, está viva e goza de boa saúde a mentalidade do tribunal plenário e inquisitorial, acusador e condenador dos agentes da renovação.

de verificação empírica. O metafísico, o sagrado, o sobrenatural, o fantástico, o sublime, o magnífico, o 'divino', isto é, o 'superior' escapa a tal verificação. Mas existe! Infelizmente, o ambiente reinante na academia tende a desconsiderá-lo; definha, a olhos vistos, a preocupação de formar para a consideração dessa dimensão exaltante do Humano. Basta consultar os planos de estudo, as ementas de objetivos e competências, bem como ponderar o peso e a extensão das matérias atinentes a esse horizonte, para não ter grandes ilusóes'.

A instituição universitária tem abandonado, paulatinamente, essa frente. E, não obstante o avolumar das alertas e até das emproadas declaraçôes solenes dos seus gerenciadores, não se descortinam sinais de um sério desejo de reverter o caminho. A generalidade dos discursos oficiais e oficiosos não passa de mero exercício de retórica, inócuo no plano das consequências. 
O que diria Einstein se voltasse ao palco universitário? Talvez o seu desassombro o levasse a falar de traição. Convém lembrar que para ele o sentido do misterioso é não somente a mais alta, profunda e sublime experiência do Ser Humano, mas igualmente o princípio básico de todo o empreendimento sério em arte e ciência. A falta dessa experiência e da necessidade dela é típica de alguém, se não morto, pelo menos cego.

A universidade continua a ser, por missão, vocação e ação, uma sede da metafísica. Porém esta transmutou-se; contenta-se em ser uma metafísica às escuras, sem luz, curiosidade e sensibilidade para tentar perceber a beleza e a sublimidade existentes por detrás do que pode ser empiricamente comprovado, e para cuja compreensão este podia abrir as portas e funcionar como intermediário.

Eis a triste, deprimente e opressiva conclusão: a autossatisfação e a soberba das certezas emparedaram ou engessaram o desassossego e a inquietude! Aquilo que hoje se apregoa e valoriza na universidade e se cultiva nas relaçôes entre os seus membros póe a nu a extensão da perda.

Deste jeito, a universidade progride, por um lado, e retrocede, por outro. Náo tem nela o devido lugar o transcendente, o que confere e amplia a relevância, o significado e a mais-valia do transcendido, ou seja, da boa e útil ciência que nela se faz. Por outras palavras, não consegue estar sob os holofotes, nas bocas e na ribalta do mundo, sem abandonar o exigido e exigente cultivo da espiritualidade e intelectualidade. O que é um paradoxo e induz uma queda na absurdidade e um resvalar para a inutilidade.

Dado o clima instalado, esta análise e outras do mesmo género suscitam animosidade. Há quem confunda a instituição com os chefes de turno, e reclame continência e respeitinho comportamental e verbal para eles. Este é um dos males que corroem a instituição na atualidade. Reina uma grande confusão: reclama-se fidelidade à universidade, tomando esta pela nomenclatura em funçóes. Ora a fidelidade tem que ser sempre para a 'ideia' da Universidade (sim, com letra maiúscula). Esta é tanto mais pujante, quanto mais recusar o discurso único e o senso comum, for aberta ao dissenso, estimular as vozes críticas dentro dela e não as penalizar e condenar à periferia.

Se a universidade impóe o silêncio aos seus membros, se lhes exige que se calem e renunciem ao dever de pensar e discordar, entấo ela percorre o caminho da morte e da perda de voz, pois seu destino é falar, tomar posiçóes, propor caminhos alternativos aos que se vão gastando. Dito de outro modo, a fidelidade reclamada só pode ser para a ideia e a missão da instituição, para a necessidade da renovação permanente, de apresentar críticas e linhas de mudança das formas e modalidade concretas de ser universidade. A tudo o resto temos razão e obrigação de ser infiéis.

Sobre a universidade impende a indeclinável obrigação de abordar numa perspetiva ética o funcionamento da sociedade. Mas hoje não tem moral para o fazer. Não está ela eivada de incontinência e indiferença no capítulo dos princípios e valores éticos? Qual é a postura dos académicos em prol de uma moral incondicional? Por outras palavras, a universidade precisa de uma severa barrela ao seu interior, se ainda acalenta a pretensão de influenciar positivamente o exterior.

Uma 'instituição' institui, ou seja, cria, funda, estabelece, divulga e promove como metro-padráo 'coisas' com escala acima do ordinário e normal. É, por isso, um instrumento de formação da plenitude da Humanidade dos humanos, de criaçáo e progresso da civilização, para bem da Ágora e da Pólis, da Sociedade e da Cidade.

As implicaçôes desta noção são óbvias para a missão e atuação de uma entidade com pretensóes de 'instituição'. O que nela acontece e se pratica deve ter irradiaçáo positiva para além dos seus muros; obriga-se a ser exemplar para a esfera pública.

A exigência vincula imperativamente as instituiçôes universitárias, devido ao facto de lhes estar confiada a formaçáo 'superior' de quadros para reger os diferentes campos da atividade. Logo, é inconcebível que se ocupem de agendas estranhas à sua causa; e tenham, à frente delas, alguém sem carácter e sem palavra, que não prime pelo cultivo dos pressupostos requeridos aos formandos. Ninguém é bom formador, se não for, no mínimo, uma pessoa iluminada pela decência, honestidade, retidão e transparência.

"O peixe apodrece pela cabeça", dizem os pescadores. As instituiçóes, nomeadamente as universitárias, também. Ora para isto contribui o inaceitável discurso de desvalorização e menorização das tarefas de ensino e formação dos estudantes, perante o enaltecimento babado dos 'papers', dos "rankings" e afins. 


\section{Quarto: das lideranças sem carisma}

A estagnação da instituição universitária decorre também do facto, assaz frequente nos últimos tempos, de ser 'liderada' (?) por figuras cinzentas, postas em bicos de pés, sem nome e sem respeitabilidade interna e, muito menos, externa. Nesta conjuntura prenhe de desafios e incertezas, a direção universitária carece, mais do que nunca, de ser exercida por gente culta e visionária, por quem seja laborioso e tenha obra feita na sua área, nome reconhecido, credível e respeitado para além dos muros institucionais e locais, e inclusive para além das fronteiras nacionais. Isto devia merecer melhor atenção!

"A única coisa que transcende a existência do ser humano é a sua obra", disse Máximo Gorki (1868-1936). É altamente pernicioso que a universidade ou faculdade, criada com o propósito de configurar uma sede da transcendência, tenha à sua frente gente desprovida de visão e vontade para idealizar, empreender e realizar obra de tomo. Isto encaminha-a, fatalmente, para a queda no anonimato, na desconsideração social e, não por último, na dormência espiritual e intelectual.

$\mathrm{O}$ exame da realidade, no tocante às possibilidades de acesso à direção universitária abertas, no caso português, pelo RJIES, convida a trazer à colação este apontamento de Oscar Wilde (1854-1900): "O nosso passado - aí tendes o que nós somos. Não há outra forma de julgar as pessoas (...) Nenhum homem é suficientemente rico para comprar o passado." Ou o de Wilhelm Dilthey (1833-1911): "O que o homem é, somente a sua história lho diz." Ou ainda o de Fernando Pessoa, sob o heterónimo de Álvaro Campos (1888-1935): "Quanto fui, quanto não fui, tudo isso sou." Para finalizar com o veredicto do Padre António Vieira, o insigne crisóstomo lusitano: "Das obras grandes ou pequenas, das açóes generosas ou vis, cada um traz na própria cabeça a verdadeira medida.”

Estas asserções e a sua compulsão com o panorama de jogos e interesses, que levam ao poder figuras sem estalão compatível com a incumbência universitária, dão muito que pensar. $\mathrm{O}$ filtro em vigor deixa chegar ao topo das pirâmides gente sem uma história dignificante, e também sem uma cabeça formada por medida edificante, ou seja, mais propensa para as coisas pequenas e até mesquinhas do que para as coisas grandes. A desertificação de ideias e ideais, de cultura humanista, de apetência e curiosidade intelectual e espiritual é uma marca ostensivamente inscrita na fronte de não poucos 'chefes' instalados nos diversos escalóes da estrutura universitária (reitorias, direçóes das faculdades, diretores de cursos e departamentos).

Trata-se de indivíduos dispostos a tudo para transitar na alameda do poder, tornando-se assim estéreis, reacionários e fechados ardilosa e silenciosamente nos seus esquemas. Não são portadores de qualquer esperança ou semente de renovação. Habitam nas cavernas, onde só há paredes, não há curiosidade e horizontes; nelas não entra a luz, nada germina e floresce. Não constroem pontes, nem cruzam fronteiras; para tanto falta-lhes, no coração e na mente, o desassossego da busca, da imaginação e da incompletude.

Não ignoro que o perfil dessa gente tem defensores arregimentados em torno da bandeira do pragmatismo da realidade. Só indivíduos com mente assaz pragmática, fabriqueira e utilitária logram corresponder à exigência desta era! O 'argumento' tem pés de barro. Poderia recorrer a uma justificação filosófica da universidade como casa de 'inutensílios' e do papel regenerador investido nestes, para pôr à mostra o projeto em curso: a perversão utilitarista e a conversão da instituiçãa em 'utensiliaria', conformando-a ao estatuto e à função de escola técnica superior. Julgo que não é necessário. Basta citar Anatole France (1844-1924): "O real serve-nos para fabricar melhor ou pior um pouco de ideal" 11 .

Ora o que hoje prende a universidade ao real e o que ela retira dele não tem contornos idealistas. Contudo, é de ideal que tanto necessitamos para respirar e sobreviver no ambiente hodierno, tão denso de doutorice economicista e tão esparso de literacia no concernente às angústias e agruras da Humanidade.

É na realidade do mundo e da nossa existência que devemos cumprir o mandamento de nos transcendermos e perseguirmos o metro-padrão do Homem: o absoluto e infinito.

Estamos hoje perante evolução ou regressão moral? Qual é a nossa opção? O que nos compete fazer? Ponhamos de lado a hipocrisia: ficamos sentados em cima do muro ou tomamos partido por um dos lados? ${ }^{\mathrm{k}}$

O sociólogo Immanuel Wallerstein adverte que todos os debates são simultaneamente intelectuais, morais e políticos, buscando aonde vamos, aonde queremos ir, como chegaremos mais facilmente. Somos desafiados a contestar a mera eficiência e a 
sua colocação acima dos direitos, a enxergar o que está à frente do nosso nariz, a confrontar os males sociais, a assumir responsabilidade por este mundo, a sair da defensiva, a regressar a um debate com base na ética e a reaprender a colocar questóes capitais.

Um verdadeiro docente da universidade, além da obrigação do apego à ciência, à cultura, à filosofia, à literatura e demais formas de arte, nunca se pode inibir de ser um cidadáo responsável e interveniente nos assuntos públicos. Somente assim pode sustentar o estatuto de intelectual, isto é, de intermediário entre as ideias e a praça da cidade.

Se não assumir estes deveres e naufragar no oportunismo, na demissão e no silêncio, por mais 'papers' que publique, ao final da sua carreira olhará em redor e verá um descampado de esterilidade e vacuidade: não deixa um rastro, um sulco, algo que inspire os seus concidadãos e mereça o apreço destes. Que desolação!

A 'paperizaçấo' ou 'papermania' faz parte de um ambiente de perda da noção de grandeza e pequenez, em que a segunda é tomada pela primeira. Não resisto, por me parecer assaz ajustado, a citar Miguel Torga (Diário 1940): "Tenho a impressão de que certas pessoas, se soubessem exatamente o que são e o que valem na verdade, endoideciam. De que, se no intervalo da embófia e da importância, pudessem descer ao fundo do poço e ver a pobreza franciscana que lá vai, pediam a Deus que as metesse pela terra dentro."

\section{Quinto: práticas de 'endogamia'}

Uma outra ameaça prende-se com a praga da 'endogamia', antiga e jamais extinta. Ela renasce constantemente das cinzas e mostra-se, mais ou menos camuflada ou exposta, na existência de dois mundos na universidade portuguesa (só nesta?):

- O neoliberal, que mantém docentes, bolseiros e investigadores em situação de precariedade, mesmo quando já adentrados na vida, sujeitos ao despedimento e a serem atirados para o caixote do lixo, à mercê dos humores dos seus patróes, ou seja, condenados a comer páo com sabor a escravidão e miséria. Ao abuso da precariedade junta-se uma burocracia rígida e formalista, gerada pelo RJIES e pelo táo adulado estatuto fundacional, que atinge todo o corpo docente.

- O feudal, manifesto nas atitudes e condutas das chefias e de alguns professores de topo. Entre os hábitos feudais, destaca-se o velho pecado da endogamia, patente em concursos feitos à medida para contratar "quem já é da casa ou já fez favores à casta", com condicionantes e "regras abstrusas que servem mais para eliminar candidatos inoportunos do que para ampliar o leque de escolha" ${ }^{\prime 2}$.

Não dá para negar o óbvio: na universidade há manifestaçốes e consequências nefastas da endogamia. Mas há que separar as águas! É inteiramente legítimo que os concursos para a progressão na carreira façam justiça a quem tem provas dadas de intenso labor e dedicação. Outra coisa bem diferente é a tentação, não rara, de somente admitir e consentir na instituiçáo indivíduos que se submetam de bom grado aos contratantes, cultivem a bajulação, o conformismo, o servilismo, a renúncia ao espírito crítico e livre. Isto, sim, é endogamia, causadora da estagnação e da morte das áreas para que são contratados; sem falar nos prejuízos para a universidade, que vai sendo, paulatinamente, povoada por sujeitos com este perfil, afeitos à nova inquisição, afundados na cobardia e subserviência, no medo de assumir a crítica e o dissenso, apegados e conformados à canga.

Muito a propósito, Rafael Barros de Oliveira formula esta denúncia: as "geraçóes atuais costumam repetir ou, na melhor das hipóteses, reformular os trabalhos realizados por seus orientadores e orientadoras e, consequentemente, treinar geraçóes futuras para seguir na mesma toada: a repetição da repetição, "ad nauseam". Ora, a força das universidades e da vida acadêmica reside precisamente em sua capacidade de abertura a novas ideias. Sem ela, é impossível à universidade realizar sua tarefa mais vital, da qual sua sobrevivência depende estritamente..."13.

Há professores com trabalho de tomo, que se vai extinguir inexoravelmente, quando da sua aposentação, por não terem escolhido continuadores à altura. Preferem ter, no seu entorno, quem não levante ondas e náo se atreva a voar para além do curral. Isto é, não fomentam o espírito e o pensamento, porquanto estes são intrinsecamente críticos e divergentes.

Tais professores não fazem, nem deixam Escola, ainda por outra razão. Hoje o que conta são os papers, porém (eis o paradoxo!) o que transita para o futuro, além da qualidade das aulas, da 
magnificência intelectual e da exemplaridade cívica, são os livros (próteses que 'livram' da ignorância); é neles que fica registado o legado de uma obra!

Os professores em causa não estão para aí virados. Porquê? Eles que respondam. Eu tenho opinião, mas náo a vou formular, pelo respeito que tenho ao seu empenho, não obstante os equívocos de que enfermam. Direi apenas, citando o poeta e crítico Paul Valéry (1871-1945), que "os livros têm os mesmos inimigos que o homem: o fogo, a humidade, os bichos, o tempo e o próprio conteúdo" ${ }^{\prime 14}$. Enquanto a valia da maioria dos papers é tanta que não suscita quaisquer inimigos! ${ }^{\mathrm{m}}$

\section{Sexto: balanço difícil}

Aonde é que isto vai levar as instituiçôes? No seio delas está colocada uma bomba de relógio; o pavio já se encontra aceso. A diminuição de estudantes de pós-graduação será inexorável, sobretudo a dos doutorandos, tanto nacionais como oriundos do estrangeiro.

Destarte, sucederá não apenas um encolhimento das verbas recolhidas com as propinas; concomitantemente, deixará de existir a mão-deobra (barata e pagante!) para escrever os 'papers', que alimentam os currículos de muitos professores e estes assinam sem qualquer escrúpulo. E a posição nos "rankings" da perversidade e falsidade, que David Justino (Diário de Notícias, 28.02.2015) equipara às "anedotas picantes", sofrerá uma queda no abismo.

A qualidade das aulas e a da formação (reduzida a instrução 'funcionalizante') faliram, faz bastante tempo. A fábrica de cursos e de 'papers' também não tardará a abrir falência.

Peço desculpa. O balanço, por mais que quisesse, não conseguiu ser risonho. Ele constitui o hemograma do inconformismo obrigatório e do pessimismo realista no tocante ao antes, ao agora e ao porvir, não sem razáo. Recorro novamente a Miguel Torga (Diário VII) para o fundamentar: "É fatal nesta pobre terra começarmos todos por ser
Para evitar um mal-entendido, desejo sublinhar o seguinte: a ciência deve suscitar em nós o sentimento de admiração e gratidão. Como esclareceu Sigmund Freud (1856-1919), o pai da psicanálise, "a ciência não é uma ilusão, mas seria uma ilusão acreditar que poderemos encontrar noutro lugar o que ela não nos pode dar" ${ }^{\prime 1}$.

Portanto a crítica à maioria do que hoje se enverniza, exibe e venera como ciência está comprometida com o enaltecimento do que é relevante e com a necessidade de abandonar a via da fatuidade, dos modismos e da irrelevância.

revolucionários e acabarmos todos em académicos. A nossa falência encontra sempre um dossel de ilusão. Cada geração que chega vem, naturalmente, possessa de desígnios subversivos. Mas como daí a pouco tempo verifica que também ela não fez nada, que falhou, que envelheceu, acomoda-se e póe-se a justificar o que a princípio combatia. Mudam-se os sinais aos manifestos de outrora, e os ímpetos juvenis passam a mesuras senis."

Eis a atitude prevalecente numa larga fatia da comunidade universitária! O conformismo e a aversão à reflexão, a pensar e a compreender, e a recusa em ver a forca, erguida à sua frente, são confrangedores; fecham portas à esperança de reversáo nos tempos que se avizinham. Ela parece mais inclinada para a cumplicidade do silêncio e da omissão do que para o protesto e a intervençáo. Não se afigura disponível para assumir responsabilidades e levantar exigências à altura das circunstâncias. Prefere andar distraída e ser entretida pelos charlatães e gurus da autoajuda, do empreendedorismo, da papermania e do sucesso. O deixa-andar e a espera de um salvador expressam a conduta generalizada e interiorizada. Para desgraça geral, a 'coisa' apresentase feia, com o céu carregado de nuvens e o sol encoberto. Não há luz no horizonte! 


\section{Conclusões}

Após uma tão longa e maçadora peregrinação, quiçá tentada pelo exorcismo, mal ficaria que não exarasse aqui algumas conclusôes, sem a aura de recomendaçôes. A exposição obedeceu à intenção de conduzir à avaliaçáo do existente e à reflexão sobre a necessidade de buscar outro rumo. Isso contém em si mesmo conclusóes e propostas. Todavia, parece curial formular umas quantas consideraçóes, consagradas ao intuito de dar alento a quem ouse erguer-se contra o estado dado.

\section{Primeiro: do intelecto, da linguagem, dos livros e da 'papermania'}

Pelo exposto, o cenário revela-se desanimador, embora não de derrota inevitável. No pódio do edifício universitário, em muitas cabeças coroadas e engalanadas com o oiro dos "rankings" e "papers", os assuntos da arte, da cultura, da literatura, da poética, da ética e da estética, etc. passaram a ser vistos como "matéria de inutilidade pública" ${ }^{4}$ (p.8-9).

É público e notório o divórcio da carreira académica com o cultivo do intelecto. A doença da falta de vida intelectual na universidade alastra; e também aumenta o número dos que a diagnosticam e denunciam ${ }^{\mathrm{n}}$. Enquanto outros preferem dar vivas ao rei, até que a nudez seja exposta, para gáudio da populaça. Pois é, a manada existe em todos os setores.

Felizmente, a "fanfarra da inutilidade", do pragmatismo e utilitarismo vem suscitando, um pouco por toda a parte, uma resistência ativa, assumida em posições e publicaçôes que falam:

- Da "cultura inculta", ou seja, do declínio da cultura geral na universidade;

- Da "desvalorizaçáo do mundo das humanidades na formação da juventude";

- Do modo consciente e deliberado ou inconsciente e ingénuo (a segunda hipótese não é melhor do que a primeira!) como "a educaçâo superior vem defraudando a democracia e empobrecendo o espírito (e o intelecto) dos estudantes de hoje";

- Da culpabilização e responsabilização dos professores pela apatia, conformismo e incapacidade de não se inscreverem no círculo criador e crítico da sociedade;

- Da conversão da universidade em barriga da ideologia dominante, que vê as vidas apenas como existências produtivas.
Os livros paradigmáticos dos pensadores e dos vates, que edificaram a 'casa do ser' e lançaram os caboucos da Humanidade, não são agora encarados como portadores de mensagens desejadas, nem têm muitos amigos à sua espera. Estão hoje abandonados ou desterrados na intemporalidade dos arquivos e nas prateleiras intocadas das bibliotecas ${ }^{\circ}$. Não se encontram mais em cima das mesas de salas de aula ou à cabeceira dos potenciais leitores. Por via disso, a linguagem e o pensamento encontram-se entregues aos serviços de urgência, aguardando cuidados intensivos ou a certidão de óbito. $\mathrm{O}$ dano é irremediável, porquanto são as palavras e vozes de tais livros, esquecidos e até dados como mortos, que nos dizem para sempre.

Era suposto que aqueles livros e o seu teor se sentissem em casa na universidade, instituição investida da suprema função de zelar pela erudição, espiritualidade, intelecto, linguagem, pensamento e transcendência da Humanidade. Mas não; são vistos como algo estranho. E não encontraram um substituto à altura, capaz de irradiar a energia humanista de que eram portadores.

$\mathrm{O}$ que na universidade se escreve, consulta e valoriza é, por certo, deveras útil, altamente meritório e até extraordinário no plano científico; mas está muito distante da claridade e luminescência dos escritos de outrora e não toca no mistério da vida, não cuida de o tornar sensível e tangível.

Todavia, queiram ou náo os que desdenham dos livros e se masturbam com os papers, estes jamais alcançarão o altar e a consagração daqueles. Foram os livros e os seus 'lentes' que ergueram a universidade e formaram criaturas geniais ${ }^{\mathrm{p}}$.

Os livros não têm prazo de validade, nem são perecíveis; o destino das suas mensagens é a eternidade. A maioria dos 'papers' não atinge a longevidade; morre na hora da respetiva publicação e contabilidade.

Os livros fazem falta à renovação do dia-a-dia, e não mordem. A maioria dos 'papers' não oxigena o quotidiano; e ferra com os dentes venenosos da vanglória.

Os livros convidam para espaços de introspeção, meditação e recolhimento. A maioria dos 'papers' pertence ao mundo da agitação e híper-aceleração. Os primeiros operam o milagre da ressurreição; os segundos são um produto da ideologia da exaustáo e estagnação, que sufoca a existência. 
As críticas feitas à 'papermania' não podem gerar mal-entendidos. Quero deixar clara esta posição: é bom que os nossos académicos publiquem em revistas de língua inglesa, divulgando assim lá fora o que de meritório se produz cá dentro. Igualmente é vantajoso que todo o académico seja fluente no manuseio de um idioma estrangeiro, no caso o inglês. Mas isso não pode ser convertido em mandamento ou rasão de conduta e avaliaçáo, ocasionando menoscabo pelas publicaçôes na nossa língua.

A muitos docentes universitários agrada mais escrever 'papers' em inglês do que livros em português. As 'razóes' prendem-se umas às outras.

A primeira, imediata e simples, ressalta à vista desarmada: os 'papers' são mais valorizados na avaliação curricular de candidaturas a concursos da carreira académica ou de projetos patrocinados pelas agências de financiamento. Acrescente-se, como espada de Dâmocles, a obrigatoriedade do 'publish or perish'. Sim, em inglês, porque em inglês nos vangloriamos e vendemos, e cometemos a vergonha de trair. A cedência ao imperialismo do inglês rende dividendos e é um emblema lustroso na lapela do casaco da pesporrência e vaidade, mesmo que salpicado pela lama da indignidade!

A segunda 'razão' é contígua à primeira: para avaliar 'papers' o critério utilizado liga-se, sobretudo, à quantidade. Para aumentar esta, basta colocar o nome em textos escritos, a maior parte das vezes, por outros, sejam eles orientandos e estudantes de pós-graduação, sejam colegas de categoria inferior na hierarquia académica. Quanto aos livros, eles são avaliados pela qualidade, e têm que ser escritos pelos seus autores, o que custa um trabalho danado (se seguir o mandamento do português escorreito) e acarreta o julgamento de um público vasto e sedento de descobrir a relevância dos assuntos versados.

A terceira ' $r a z a \tilde{o}$ ' prende-se com a proficiência linguística. Para publicar 'papers' não é necessário um amplo e superior domínio do inglês; basta conhecer um vocabulário reduzido e simplificado, que dá pelo nome de 'globish' e permite comunicar de forma rudimentar, empobrecida e empobrecedora, à escala global.

Por conseguinte, a defesa do português não tem implícita unicamente uma revolta contra o 'imperialismo do inglês'; contém fundamentalmente uma recusa da superficialidade do 'globish', porquanto ela atenta contra o conceito fundador da universidade e contra a idiossincrasia e identidade de um lídimo professor universitário.

O abastardamento da linguagem, hoje em curso na universidade, expressa e induz o abastardamento da profissão de docente, do ensino e de outras dimensões axiais da missão universitária, a preferência pelo líquido e efémero, pelo superficial e volátil, em detrimento do constante e custoso, do sólido e duradoiro. A indigência argumentativa, a contrafação da razão e do conhecimento, a falsidade da "Logos", a inautenticidade da "Ethos", o fingimento da "Pathos", a queda na absurdidade e a formatação do sujeito incaracterístico andam pelas ruas da amargura, e coabitam com cama feita, mesa posta e roupa lavada, casados em comunháo de bens ${ }^{\mathrm{q}}$.

A língua portuguesa dispóe de uma riqueza extraordinária e incomparável no plano concetual, lógico, metafórico e semântico. Dominá-la com propriedade fiadora de elevação intelectual e espiritual, eis uma competência que devia estar ao alcance de muitos - e ser obrigatória e basilar na universidade! Porém, são poucos e cada vez menos os universitários que fazem parte de tal universo; ao invés, são muitos e cada vez mais os que tratam a nossa língua a pontapé, com erros grosseiros nos textos e nos pronunciamentos orais.

Entre a linguagem (escrita ou oral) e o pensamento há uma relação de intimidade e reciprocidade, que associa a forma e o conteúdo. A linguagem representa a forma, o nível, a densidade, o fulgor e a luminosidade das ideias - ou a sua penúria, fragilidade e ausência. As palavras revelam a grandeza mental, a arquitetura, o conteúdo, a ordem e o rendimento do pensamento que as anima. Uma linguagem débil, enfraquecida, com trancos e barrancos, sem clareza e esplendor traduz um estado igual do pensamento e raciocínio. A confusão e a pobreza da linguagem deixam à mostra idêntico estado performativo do pensamento. O labor de aprimoramento da linguagem e, ao invés, o descaso linguístico repercutem-se no pensamento; o nível das palavras 'por fora' expóe o primor do intelecto, da cognição e racionalidade 'por dentro'.

Karl Kraus (1874-1936), escritor e poeta austríaco, é perentório: "A linguagem é a mãe, não a criada do pensamento." Deixemo-nos de paninhos quentes e salamaleques: quem não sabe escrever e falar conforme à norma culta e erudita, também não logra pensar conforme aos requisitos próprios do desempenho em sede universitária. Esta maleita é notória e propaga-se, ameaçando contaminar, de uma ponta à outra, a tapeçaria académica. Por este andar, não tarda nada, Diógenes vasculhará de candeia acesa os recantos da universidade, à procura de quem saiba escrever e falar escorreitamente, e não o encontrará!

A linguagem fornece-nos o leite da integraçáo no mundo: os valores, os princípios, os ideais, sonhos e 
inclinaçôes; os modos de perguntar e responder, de observar e entender, de aperceber e valorar, de ser e estar.

Portanto, quando advogamos a defesa e o cultivo esmerado da língua portuguesa na universidade e pelos respetivos docentes, não somos impulsionados por uma causa de segunda ordem ou por conveniências e motivaçóes pessoais. Estamos a pugnar pela renovação do legado matricial e central da universidade: a incumbência de ser casa da espiritualidade e intelectualidade, da sabedoria e da erudição.

Não se subestime este pressuposto: um doutor é um profissional da palavra e do ministério de a escrever e dizer com estilo erudito, esbelto e perfumado, claro e sublime, ético e estético, atraente e quente, e não feio e repelente. Deve, pois, ser formado como cultor do uso maior e do poder e esplendor da palavra. A lógica científica, epistemológica e filosófica pede a companhia condizente e colaborante de um convincente nível retórico.

Os muros entre a ciência e a palavra são aberrantes. A sociedade seria muito escura e pobre sem o cultivo da ciência. Mas igualmente apagada e mísera sem o condáo da palavra; sem as diferenças e complementaridades que ligam os dois campos da imaginação humana.

Na palavra vinculamo-nos ao enigma, ao mistério. A ciência vincula-se às coisas sonhadas. Na palavra não há razão; há o fascínio pela perfeição da estética inatingível. A ciência tem razão, quase nunca plena, mas indispensável. A palavra tem corpo e forma; a ciência cuida da funçáo. Na palavra mora a intimação da pergunta; na ciência move-se a possibilidade da resposta. Na palavra procura dizer-se o que náo se sabe; na ciência diz-se pouco do que se conhece. A palavra é ousada; a ciência comedida. Na palavra procura-se o insondável; na ciência o cognoscível. A palavra é uma provocação; a ciência consequência. A palavra é vocação; a ciência obrigação. A palavra é argumentação; a ciência construção. Na palavra mergulha-se no obscuro; na ciência vai-se pelo caminho da luz. A palavra quer desvendar a fonte da vida, a amplidão da alma; a ciência os limites da natureza. E é aqui que a ciência se abeira da palavra, porque a natureza gosta de se esconder. A palavra encerra o mérito de ajudar a encontrá-la. Por isso ela, a 'logos', vai sempre à frente. No princípio era o verbo!

Afinal, a palavra é uma canseira, ganha num longo e esforçado caminho, por cumprir ordens de desejos também curiosos e inteligentes, e de olhos porventura mais ousados e videntes.

Concluamos esta deambulação, afirmando, sem rodeios, que a universidade não será um laboratório de ciência e formação, se não for uma 'catedral da Palavra', de palavras que elevem a norma pública. Para isso tem que obviar a perda da sua substância, porquanto a degradação e a banalização da linguagem acarretam o empobrecimento do pensamento.

A palavra 'universitária', para o ser e honrar a sua génese, tem que procurar compreender e avaliar o universo de facetas que qualquer assunto apresenta. $\mathrm{O}$ que intima à tecelagem discursiva, fazendo-a passar pelo crivo do pensamento contra si mesmo e da preocupação em saber questionar a tese que não defendemos.

Isto obriga-nos a recuperar o primado da liberdade interior e a introduzir esta no processo de elaboração e circulação do discurso público; obriganos a renunciar ao acomodamento e ao conforto paralisante dos estereótipos do senso comum e do linguajar vigente.

Só assim podemos dar um contributo válido para a ascensão da ágora, da 'polis', da cidade e da democracia a um patamar superior. Ele é deveras requerido aqui e agora; basta prestar atenção ao que mais abunda por aí, na televisão, nos jornais, na blogosfera: debilitação do debate, repetição de litanias superficiais, recusa da complexidade, invocação de receitas mágicas, moralismo ingénuo, exibicionismo opinativo sem fundamentação, supressão da crítica exigente e culta, um palrear a raiar os limites da cretinice, infantilização geral da sociedade, fuga à realidade e um consumismo de 'slogans' e patranhas semelhante ao de coisas materiais.

Se descurarmos o imperativo de confecionar e iluminar a palavra com o brilho cintilante das estrelas da altura, da ética e da estética, estaremos a tecer o nó do nosso enforcamento. Ela, a palavra luminosa, é o fio do prumo do compromisso com a inalienável procura da verdade, mesmo que esta seja inalcançável.

\section{Segundo: da pós-graduação}

Naturalmente, não é realista a expectativa de que todos os docentes e pesquisadores sejam expoentes do cultivo do intelecto, do pensamento abrangente e complexo (Edgar Morin). Quem esperar isso condena-se à espera em vão, à desilusão e frustração. Aquela cultura devia imperar e prosperar na universidade, mas é descurada. Tal inquietação não informa a estrutura dos cursos de graduação e pósgraduação, a ementa de parâmetros avaliadores dos trabalhos produzidos e dos seus autores; não tem nada a ver com isso a progressáo na carreira académica. Ao invés, regista-se a consagração da fragmentação e a 
marginalização da abordagem complexa de temas, por natureza, complexos e polissémicos. Os grandes e tão difíceis problemas da nossa era, repleta de incertezas, são abordados separadamente, sem uma visão ou ponte que os conecte.

Este panorama coloca desafios a todos os cursos, particularmente aos de pós-graduação. O sucesso de ontem pode degenerar em irrelevância amanhã, se hoje cair no adormecimento da autossatisfação. É minha profunda convicção de que a pós-graduação, sobretudo ao nível do doutoramento, carece de ser perspectivada como escola do pensamento avançado na respetiva área. Isto implica alteraçóes na estruturação, no funcionamento e nas suas metas, visando corresponder ao desígnio apontado.

Para ser mais concreto e assumir a responsabilidade de desencadear uma reflexão atinente, vou atreverme a algumas teses e provocaçóes.

Não estará algo consumida e ultrapassada a estruturação segundo o tradicional modelo disciplinar? Não será chegada a hora de encerrar uma etapa altamente frutífera e meritória, e de partir para nova aventura, por certo nada fácil, mas deveras aliciante e promissora, como seja a organização da pós-graduação (a nível de doutorado) em torno de grandes temas (p. ex., aprendizagem, corpo, desenvolvimento motor, envelhecimento, obesidade, rendimento), solicitadores de abordagem multidisciplinar? Isto não invalida o conhecimento disciplinar; antes requer o seu aprofundamento e o comprometimento dos respetivos especialistas no lançamento de pontes com outras disciplinas e modos de imaginar e pensar. Não resultaria esta evolução em benefício da formação dos estudantes e professores, e da renovaçáo da área científica?

Creio que, na consecução deste desiderato, auxiliarnos-ia o suporte dos ensinamentos de Lev Vygotsky (1896-1934 e de Maria Montessori (1870-1952), colocando a fasquia da estrutura um pouco acima das condiçóes em que nos habituamos a funcionar.

Não temos soluçôes prontas e acabadas. Também aqui se aplica o incitamento dos versos do poeta andaluz António Machado (1875-1939): "Caminante, no hay caminho, se hace caminho al andar (...) Caminante, no hay caminho, sino estrelas en la mar." É pelo brilho da lonjura que nos devemos deixar atrair e guiar.

"O começo é a metade do todo", proclamaram os clássicos gregos. Se vencermos o receio, compreensível e natural, de abandonar as roupas usadas e tivermos a ousadia de inaugurar um percurso distinto do atual, consonante com a perspectiva acabada de expor, estaremos nesse preciso momento a meio do chamativo e reconfortante final.
Toquemos noutro ponto. $\mathrm{O}$ ensino universitário diz-se 'superior'. Qual é o significado e a consequência desta pretensão? Obriga-se a ser 'superior' numa pluralidade de dimensóes, que se interligam e fertilizam mutuamente. E a fazer a respetiva demonstração. Ou seja, cumpre-lhe ser 'superior no plano científico, cognitivo, crítico, espiritual, intelectual, ético, estético, cultural, cívico, comportamental, moral e racional.

Está acordada na pós-graduação a consciência destes alvos? Repercute-se nas modalidades da sua organização, na orientação e avaliação dos estudantes, da sua formação e trajetória, e dos trabalhos por eles elaborados?

A dissertação de um doutor não é apenas o produto de um processo mais ou menos laborioso; ela deve comprovar sobejamente a promoçáo e qualificação do seu autor no concernente a tais parâmetros. Nesta conformidade, no ato da avaliação final, ele tem que ser confrontado com exigências e evidências neste domínio. Em que medida e com que nível atingiu os alvos pré-estabelecidos? Que livros e leituras o acompanharam durante a caminhada para a obtenção do grau? Que músicas adoçaram o seu coração? Que poesias extasiaram e inebriaram a sua imaginação? Que pinturas alargaram e aguçaram o seu olhar? Que valoração faz do chão andado, da transformação nele operada, enquanto académico e, sobretudo, pessoa? Como se julga e posiciona perante a área académica e os seus pares, a missão da universidade e as obrigaçóes de um quadro intelectual?

A tấo badalada e glorificada exigência de competência cientificista e tecnocrática encobre desajeitadamente uma requintada hipocrisia: o intencional estreitamento do espectro de saberes, com vincado menosprezo de tópicos inerentes à antropologia, à filosofia, à política, à sociologia, isto é, à Humanidade e Sociedade. Interpretemos a mensagem subjacente: para o florescimento da 'sociedade do conhecimento' (o último achado ideológico!) são inúteis e dispensáveis quadros culturalmente esclarecidos e civicamente interventivos. Nem mais, nem menos!

Não ladeemos questôes fulcrais! Queremos fabricar doutores (e professores universitários!) mentalmente acríticos e cegos para os assuntos da Pólis? Será isso que almejamos?

António Figueiredo, num fecundo ensaio sobre as "competências para as novas gerações", propóe um mosaico apelativo e pertinente de "competências fundacionais", "competências para aprender e inovar", "competências emancipatórias" ("as mais 
desesperadamente necessárias aos jovens cidadãos dos nossos dias), "competências humanisticas e artísticas" e "competências sociais e emocionais", todas entrelaçadas entre si. Fundamenta o autor: "Se as competências anteriores são essenciais à sobrevivência do indivíduo nas próximas décadas, arrisco-me a sugerir que as competências humanísticas e artísticas poderão ser essenciais à sobrevivência da civilização. Com os algoritmos e sistemas de aprendizagem automática a reproduzirem-se em roda livre, nas mãos do grande capital sem escrúpulos e de técnicos sem dimensão cultural que não seja a da sua específica e restrita especialidade, podemos estar a encaminharnos a passos largos para uma catástrofe civilizacional - que até já se anuncia! Onde estarão as competências culturais e transdisciplinares superiores capazes de dar sentido humano aos resultados debitados mecanicamente pelas análises maciças de dados? Quem será capaz de vigiar os erros e preconceitos que alimentam essas análises e que estáo, muitas vezes, na base da concepção dos algoritmos? Ou conseguimos formar cidadãos com a dimensão cultural, social, filosófica, ética, histórica, política, estética, artística necessária para humanizar a tomada de decisão e gritar que o robô vai nu, ou arriscamo-nos a assistir, ainda neste século, a grandes tragédias"16.

Para mim o ideal de doutor revê-se na imagem e proficiência de Noé, na capacidade para selecionar e congregar elementos de variadas proveniências numa construção de harmonia, com eles pairar sobre a tempestade das circunstâncias, superar e transcender ventos e procelas, e garantir a continuidade auspiciosa e sublimada do que encontrou na sua entrada em cena.

Evidentemente, isto não se compagina com a ingenuidade patenteada por não poucos doutores recém-formados. Colocados de chofre na parte cimeira da pirâmide, desprovidos de razóes para contestar ou defender o quer que seja, habituados a atitudes e linguagens de ambiguidade, tornam-se cúmplices e sustentáculos de projetos sem o seu quinhão de poder. Olham em redor e veem terra eternamente virgem, onde nada se pode plantar. Cuidam que a generosidade do céu jamais faltará à chamada; dele descerá, infalível e miraculosamente, o maná em porçôes abundantes. Basta um estalido dos dedos ou uma oração!

Permitam-me rematar este item, aduzindo um testemunho filiado na carreira académica. Durante a docência universitária entendi sempre a formação dos estudantes como um processo de aprimoramento de pessoas destinadas a exercer funções em atividades adstritas ao desporto e à educação física. Assim considerei e assim procurei agir. Incentivando-os a que se formassem como sujeitos avessos ao primarismo e vulgaridade boçais, abertos à sublimação das fraquezas, conscientes das consequências das suas atitudes e açóes, com fé naquilo que nos transcende, ilumina, inspira e fortalece a capacidade de distinguir o bem do mal, e de optar.

'Pessoa' provém do vocábulo latino 'Persona', que significava 'máscara'. Tornamo-nos 'Pessoa' à medida que, por cima das falhas e debilidades, da ignorância e da animalidade dos impulsos e instintos, colocamos uma máscara ou camada espessa de noçóes, saberes, qualidades e padróes de conduta definidores do Ser Humano.

As competências e ferramentas operativas de uma profissão alteram-se com os tempos. Os traços definidores de um profissional, que corresponda a uma pessoa autenticamente 'superior' nos planos atrás apontados, esses não mudam; são supratemporais.

Acalento a convicção de que os atributos da 'boa' pessoa franqueiam as portas ao 'bom' profissional. Ou seja, preparar profissionais para qualquer ofício é, antes de mais, formar 'pessoas qualitativas' como príncipes inter pares, propensas a 'professar' a crença nos princípios exaltantes da existência.

Não conheci, ao longo da vida, nenhum profissional irradiador de influência positiva que não fosse uma personalidade exemplar. Os bons professores, que tive no ensino básico, secundário e superior, eram excelentes pessoas, marcos geodésicos da cidadania. É por isso que os guardo no arquivo da memória, da admiração e da saudade.

Mas...como avaliar a qualidade de uma pessoa? Bem, a pessoa é os valores que perfilha! Proponho como bitola o índice do apego às virtudes humanas, reunidas no esquema das quatro virtudes cardeais ou cardinais, que polarizam todas as restantes.

Com elas evocamos disposiçôes habituais e estáveis da inteligência e da vontade, que regulam os nossos atos, ordenam as nossas paixóes e guiam a nossa conduta, sob os ditames da razão. São adquiridas e reforçadas pela prática repetida de atos moralmente bons. A ementa e o teor das mesmas são os seguintes:

- A Sapientia/Prudência predispóe para discernir, em todas as circunstâncias, o verdadeiro bem e escolher os justos meios para o atingir. Ela conduz às outras virtudes, constitui o capitel da coluna virtuosa, indica-lhes as vias de realização, sendo por isso considerada a virtude-mãe.

- A IustitialJustiça expressa a disponibilidade para conceder aos outros o que lhes é devido. 
- A Fortitudo/Fortaleza prodigaliza a coragem e a firmeza no enfrentamento das dificuldades e a constância na custosa procura e afirmação do bem e da verdade.

- A Temperantia/Temperança assegura a moderação na atraçáo pelos prazeres, garante a prevalência do ânimo volitivo sobre os instintos, e proporciona o equilíbrio no usufruto dos bens criados.

A estas acrescem 'pequenas' virtudes, contributivas para um mundo e uma vida melhores, tais como: amor à verdade, autenticidade, boa-fé, bonomia, confiabilidade, decência, fidelidade, franqueza e frontalidade, generosidade, gentileza, gratidão, honestidade, honra, humildade, lealdade, misericórdia, parcimónia e polidez nos gestos e nas palavras, respeito pelo próximo, simplicidade, sinceridade, solidariedade, tolerância, verticalidade, etc ${ }^{17-18}$.

Não tem isto nada a ver com a pós-graduação e a formação de mestres e doutores? Eu acho que tem - e muito. Não estou eivado de fervor missionário; tento apenas escutar e ressoar os gritos desta nossa época esvaziada de nobreza de carácter e de sadio relacionamento $\mathrm{t}$.

\section{Terceiro: apelo a uma revolução suave}

Em jeito de síntese, reafirmo que a laboração das consideraçóes exaradas nestas páginas não se moveu pelo fito de concitar aplauso e concordância. Ela atingiria a gratificação máxima, se despertasse as forças críticas, estranhamente adormecidas e apáticas; e fosse contradita por análises e reaçóes fundamentadas. E, sobretudo, se avivasse a consciência da necessidade de uma revolução suave.

Nesta era de caminhos bifurcados, a universidade devia ser a sede ideal de uma insurgência, sem sangue e virulência nas intençôes, nas palavras e nos atos. O seu coração não está definitivamente contaminado, pode soltar brados e erguer pendóes, que desencadeiem e incendeiem a esperança numa 'revolução suave' ${ }^{19}$.

Estamos encalhados num modelo de sociedade e universidade. Somente sairemos dele, se tivermos a coragem de o dar por gasto, e de encarar a busca urgente de ideias e perspetivas de superaçáa, que abram caminhos novos. Náo é possível aliar produtivismo com brilhantismo e excelência ${ }^{20}$.

Acordemos e clamemos por claridade e renovação! A desdita do presente reza e suplica por urgente substituição.

Caríssimos Leitores, Professores e Estudantes:

Peço-lhes desculpa por esta mimese do Sermão de Santo António aos Peixes, do Padre António
Vieira. Acreditem, fiz a viagem carregado de bons propósitos! Procurei desobrigar a consciência e adubar a convicçáo de que a universidade tem uma matriz própria e um destino invencível. O que eu queria era que ela estivesse no centro da cidade, como uma altiva catedral gótica, com vitrais flamejantes, no lugar dos bancos. Antevejo que, mesmo moribunda, tarde ou cedo vai renascer das cinzas, levantar-se e expulsar os corpos estranhos. É o que a salva a ela e a nós...e a torna notável e insubstituível.

Por favor, não se omitam, prestem atenção, avaliem e acudam ao estado de degradação da 'formaçâa' e da 'contemplação'! Elas não têm espaço nem tempo suficientes para uma respiração pausada. Falta-lhes a medida justa de "otium" garantidor de alento, do que nos habita e preenche, acalenta e anima, move, orienta e regula por dentro. Sem ele não há espírito! Não vamos lá com vocabulário limitado e imagética pobre, com palavras gastas e vulgares. Convém ler mais para escrever melhor e dar ao conhecimento o 'sabor' do 'saber'.

O que faz falta para assumir os desafios projetados e ir ao encontro das causas e ideais esquecidos e abandonados? Reparemos na observação de Edgar Morin: "Há apenas dois caminhos: o abismo ou a metamorfose. Rumo ao primeiro não é preciso esforçar-se, pois a ele nos empurram nossas carências e incompreensôes. A direção do segundo caminho, porém, precisa ser cuidadosamente apontada." E ainda: "Náo se pode reformar a instituição sem antes reformar as mentes, mas não se pode reformar as mentes sem antes reformar as instituiçóes" 21 .

Não ensinamos o que dizemos; transmitimos o que somos. O que é que então se exige para romper o colete-de-forças que comprime a universidade?

Algo muito pequeno na formulação, porém exigente na açáo: coragem e lucidez! Ou as temos ou não. Se as temos e não usamos, somos cobardes; se as não temos, somos carentes e dementes.

Tanto num como no outro caso, não estamos à altura de cuidar de outrem; carecemos de alguém que cuide de nós. Logo, sejamos honestos, justos e precisos: o nosso lugar náo é no areópago universitário; é num hospício!

Enfim, a edificação de um novo Humanismo e Iluminismo é indispensável, se quisermos perceber e equacionar as ansiedades e perplexidades contemporâneas. E estas dizem respeito a todos nós, independentemente do estatuto e dos pontos de vista de cada um. Logo, elas solicitam a nossa mobilização, discussão e reflexão. 
Quem conhece o passado dispóe de mais referências e rotas para congeminar o futuro. Por isso, talvez devêssemos voltar atrás e descer aos poróes, onde repousam liçôes de vida e de sabedoria, vertidas nos documentos e livros há muito não lidos. Não nos espantemos, se formos surpreendidos por raios cintilantes que atravessam a poeira do abandono, nos enchem de luz os olhos, o coração e alma, e incendeiam a boca e as mãos.
Termino, fazendo meu o voto de Miguel Torga:

"É impossível que o tempo actual não seja o amanhecer doutra era"22.

Para o concretizar, não ignoremos que, sob a capa da 'novidade' e da 'inovação', hoje assaz propaladas "urbi et orbi", escondem-se coisas obsoletas, relhas e ultramontanas, mais velhas do que a Sé de Braga. Novo somente o que é eterno!

\section{Notas}

a. O leitor deve reparar no facto de, ao longo do texto, escrever em letra pequena as palavras 'universidade' e 'faculdade'. "In illo tempore", eu usava a letra maiúscula; se agora escrevesse destarte, alinharia com a tragicomédia posta em cena e falsearia a realidade.

b. Para algumas das citações, feitas no texto, não é indicada a fonte. Peço muita desculpa, mas apanhei-as aqui e ali (em conferências, no facebook, em leituras de jornais, etc.); e não tive o devido cuidado em registar essa origem.

c. Recomenda-se a leitura do livro Psicopolítica, da autoria de Byung-Chul Han, onde a teia deste controlo é exposta e desmontada com clarividente proficiência.

d. A história da universidade contém muitos capítulos sobre a traição. Por exemplo, quando o Marquês de Pombal (16991782) decidiu eliminar dos registos dos cidadãos quaisquer referências à sua condiçấo de judeus ou cristấos novos, a Universidade de Coimbra ofereceu uma tenaz resistência. Em tempos mais recentes, a Universidade Humboldt, de Berlim, foi um ninho de corifeus do nazismo. Nos nossos dias, outras formas de traição poluem o ambiente universitário.

e. A Lei no 62/2007, de 10 de setembro, criou um 'novo' cenário orgânico das universidades e institutos politécnicos, manifestamente balizado por bitolas empresariais e 'managerialistas', em conformidade com o 'mainstream' ideológico de pendor ultraliberal.

f. "A vida não presta sem milagres. E, para os haver, é necessário que alguém acredite neles." Esta asserção é da lavra de Miguel Torga. Aparentemente aplica-se ao regime fundacional; mas realmente é só na aparência, porquanto não se afigura credível que os paladinos de tal regime acreditem no milagre, por eles a toda a hora propalado e inscrito no estatuto fundacional. Com efeito, o que moveu e move os arautos do dito regime não são os argumentos que eles publicitam. O seu fito é o de, por semelhante via, poder escapar a alguns constrangimentos legais, que obrigam a gestão da coisa pública, e de implementar mais facilmente a visão managerialista. Acresce, cuidam eles, a possibilidade de ter à mão mecanismos mais flexíveis de celebração de contratos de trabalho com baixos salários e com vínculos de precariedade. Ora isto não se compagina com a idoneidade inscrita na matriz de uma instituição do ensino superior e no perfil dos seus dirigentes. Pasmo com o à-vontade desta gente: esquece táo facilmente que nem tudo o que é legal tem legitimidade moral, e que a legalidade de muitos procedimentos é questão de poder e não de justiça! Será isto esquecimento ou será, antes, uma expressão das lacunas da sua formação? Venha o diabo e escolha.

De resto, este recurso faz parte do arsenal neoliberal de estratagemas, receitas e reformas estruturais, com as intençôes e consequências sobejamente conhecidas.

g. O CG-Conselho Geral é o órgão de cúpula das instituições de ensino superior portuguesas; foi criado pelo RJIES e está acima do reitor. Este passou a ser escolhido pelo CG, composto por 15 a 35 membros. Por exemplo, na Universidade do Porto, o CG é constituído por 23 membros: 12 docentes, quatro estudantes e um funcionário, eleitos pelos pares; seis membros externos, cooptados pelos conselheiros eleitos. O Presidente do CG é eleito entre os cooptados. Consequência evidente: além do roubo do direito democrático da comunidade académica de eleger o reitor, no CG não têm representação várias faculdades, dado o seu peso eleitoral, inferior ao das escolas grandes.

As instituiçôes, que adotam o estatuto de fundação, como é o caso da Universidade do Porto, possuem ainda um Conselho de Curadores, composto por cinco elementos externos, nomeados pelo governo, sob proposta da instituição. Esse conselho homologa várias das deliberaçóes do CG, nomeadamente a de designação e destituição do reitor, além do poder de nomear e exonerar o conselho de gestão. Enfim, uma teia de burocratização e de perda de autonomia, ao contrário do afirmado na legislaçáo e do propalado pelos paladinos do 'managerialismo'! 
h. Aconselha-se a leitura destas reflexóes: Barnetr ${ }^{23}$ e BAILEY ${ }^{24}$.

i. Aconselha-se a leitura desta obra de: Gilles Lipovetsky e Jean Serroy ${ }^{25}$ (p.400-1).

j. Edgar Morin alerta-nos para a necessidade de tomada de consciência da progressão da 'inteligência cega': "Adquirimos conhecimentos inauditos sobre o mundo físico, biológico, psicológico, sociológico. Na ciência há um predomínio cada vez maior dos métodos de verificação empírica e lógica. As luzes da Razão parecem fazer refluir os mitos e trevas para as profundezas da mente. E, no entanto, por todo lado, erro, ignorância e cegueira progridem ao mesmo tempo que os nossos conhecimentos.

Necessitamos de uma tomada de consciência radical:

1. A causa profunda do erro não está no erro de fato (falsa percepção) ou no erro lógico (incoerência), mas no modo de organização de nosso saber num sistema de idéias (teorias, ideologias);

2. Há uma nova ignorância ligada ao desenvolvimento da própria ciência;

3. Há uma nova cegueira ligada ao uso degradado da razão;

4. As ameaças mais graves em que incorre a humanidade estão ligadas ao progresso cego e incontrolado do conhecimento (armas termonucleares, manipulações de todo tipo, desregramento ecológico, etc.).

Gostaria de mostrar que esses erros, ignorâncias, cegueiras e perigos têm um caráter comum resultante de um modo mutilador de organização do conhecimento, incapaz de reconhecer e de apreender 'a complexidade do real'”26 (p. 9-10).

k. Muitos académicos dizem-se politicamente 'neutros'; à sua hipocrisia aplica-se como uma luva o veredicto de Max Weber (1864-1920): "Neutro é quem já se decidiu pelo mais forte".

Mais, a hipócrita invocação de 'neutralidade' é uma forma abjeta e cobarde da cumplicidade com o mal e a indecência, e da recusa em assumir a responsabilidade de pronunciamento e de tomar posiçấo. Ela merece esta cajadada de JeanJacques Rousseau (1712-1778): "A ciência sem consciência destrói a alma."

1. Estou consciente de que as críticas, que faço aos 'papers', podem ser subscritas por aqueles que não fazem nada e vivem, seja perdoada a expressão, à sombra da bananeira. Entendamo-nos: não confundamos o dever da produtividade, indissociável da docência universitária, com a insana deriva do produtivismo! Na ementa de atribuiçóes de um docente universitário insere-se a da produção e publicaçáo de estudos, de artigos, de livros e manuais relevantes para os estudantes, para o grupo sócio-profissional e para o público em geral. Muitos 'papers' são altamente meritórios. Porém, a maioria deles alinha por outro diapasão: o objetivo centra-se em si mesmo, servindo para a prestação de contas dos seus atores face a exigências de avaliação e financiamento. Tudo o resto é desconsiderado. Por isso, eles são hoje um dos instrumentos de degradação da docência, alvo de denúncia e crítica por um crescente número de prestigiados nomes da ciência e da academia.

m. Obviamente, as generalizaçôes carecem de justiça. Há 'papers' de excelente qualidade; todavia são cada vez mais frequentes as denúncias e tomadas de posição que catalogam a maioria deles como 'inservíveis' e de 'andar por casa'. Veja-se, por exemplo, a proclamação, publicada no jornal EL PAÍS, de 10 jan. 2017, com este título sugestivo: "La ciencia vive una epidemia de estudios inservibles - Científicos de EE.UU., Reino Unido y Holanda denuncian que la investigación está perdiendo parte de su credibilidad."

n. Veja-se: The Slow Professor movement: reclaiming the intellectual life of the university (https//l.facebook.com/l. php?u=www.cbc.ca/player/play/879028291614).

o. Vem a propósito citar o escritor norte-americano John Steinbeck (1902-1968): "Pela grossura da camada de pó que cobre a lombada dos livros de uma biblioteca pública pode medir-se a cultura de um povo" ${ }^{\text {27. }}$. Creio que isto se aplica inteiramente ao padrão cultural das comunidades académicas dos nossos dias.

p. Como se sabe, o 'lente' (oriundo do latim "legende": que lê) era o docente da universidade. Na aula ele lia o manuscrito ou, mais tardiamente, o livro para os estudantes. Estes tiravam apontamentos com os quais faziam as renomadas sebentas. Em alemão, a aula teórica ou palestra do professor mantém a designação de 'Vorlesung', termo que, traduzido à letra, significa 'leitura perante' os estudantes.

q. "Só quem está em estado de palavra pode enxergar as coisas sem feitio", afirmou Manoel de Barros (1916-2014), poeta do Pantanal brasileiro.

r. "A norma culta, a dominante, a que é ensinada como correta, (....) é necessária para preservar e aprimorar a precisão da linguagem científica e filosófica, para refinar a linguagem emocional e descritiva, para conservar a índole da língua, sua identidade e, consequentemente, sua originalidade. Ao contrário do que entendi de certas opiniôes que li sobre o assunto, a norma culta não tem nada de elitista, é ou devia ser patrimônio e orgulho comuns a todos. Elitismo é deixá-la ao alcance de poucos, como tem sido nossa política"28.

s. O esquema das quatro virtudes deriva de Platão e foi adaptado para o cristianismo por Santo Ambrósio (340-397), Santo Agostinho de Hipona (354-439) e São Tomás de Aquino (1225-1274).

48 • Rev Bras Educ Fís Esporte, (São Paulo). 2017 Ago; 31(N esp):27-49. 
t. As pressôes para o aumento do produtivismo, a obsessão pelas métricas do desempenho e o frenesim da competitividade e do "publish or perish" implantaram-se nas nossas universidades mais por contágio e importação do que por reflexão própria. Daqui resultaram métodos e regulamentos de avaliação, que, em vez de favorecer o propalado desígnio da 'melhoria do desempenho', serviram essencialmente para criar um clima intimidatório, e para degradar as relaçôes entre colegas. E também em nada contribuíram para a melhorar as condiçôes de trabalho; antes as agravaram, juntando-se-lhes o problema do subfinanciamento e a precarização crescente. Não adianta pretender aperfeiçoar os instrumentos avaliativos do desempenho. A preocupação com o termómetro não faz baixar a febre! Importa, sim, receitar os remédios certos para pôr cobro à loucura da avaliação e competitividade, causadoras do estado febril contaminador que afeta a vida académica.

\section{Referências}

1. Escrito na Pedra. Jornal Público. 6 ago. 2016;64.

2. Amaral AL. E dizer não, não, não! Jornal Público. 10 dez. 2012;47.

3. Escrito na Pedra. Jornal Público. 19 mar. 2017;29.

4. Jorge L. Os mitos que nos visitam. Porto: Faculdade de Letras da Universidade do Porto/Oraçóes de Sapiência; 2013.

5. Torga M. O Alentejo. In: Portugal. 5a ed. Coimbra; 1986. p.119-29.

6. Byung-Chul H. A sociedade do cansaço. Lisboa: Relógio D’Água; 2014.

7. Nietzsche F. Humano, demasiado humano. Lisboa: Círculo de Leitores, 1996. (Obras Escolhidas de Nietzsche; vol.2).

8. Byung-Chul H. O aroma do tempo. Lisboa: Relógio D’Água; 2016. p.129.

9. Morin E. O verdadeiro papel da educação. Rev Prosa Verso Arte.

10. Morin E. É preciso ensinar a compreensão humana. Rev Prosa Verso Arte.

11. Escrito na Pedra. Jornal Público. 4 jun. 2015;48.

12. Tavares R. A universidade feudal-neoliberal. Jornal Público. 13 jan. 2017.

13. Oliveira RB. O sofisticado nepotismo das universidades brasileiras. Terraço Econômico. 22 fev. 2017.

14. Escrito na Pedra. Jornal Público. 5 fev. 2017;29.

15. Escrito na Pedra. Jornal Público. 8 mar. 2017;42.

16. Figueiredo A. Que competências para as novas gerações? [Internet - Facebook]. [citado 7 mar. 2017].

17. Comte-Sponville A. Pequeno tratado das grandes virtudes. São Paulo: Martins Fontes; 1999.

18. Domingues FB. Virtudes para um mundo melhor. Jornal Público. 13 mar. 2011;32.

19. Gilles Lipovetsky \& Jean Serroy, ibidem.taon 17

20. Berg M, Seeber BK. The slow professor: challenging the culture of speed in the academy.: University of Toronto; 2016.

21. Morin E. A via para o futuro da humanidade. Rio de Janeiro: Bertrand Brasil; 2013.

22. Escrito na Pedra. Jornal Público. 13 mar. 2017;43.

23. Barnett R. Being an academic in a time-impoverished age. In: Amaral A, Bleiklie I, Musselin C, editors. From governance to identity. Dordrecht: Springer; 2008. p.7-17.

24. Bailey RW. Is the university in ruins? Birmingham: Institute for Economic Development Policy/University of Birmingham; 2008. ( Discussion Paper n. 2008-2).

25. Lipovetsky G, Serroy J. A estetização do mundo: viver na era do capitalismo artista. São Paulo: Companhia das Letras; 2015. 26. Morin E. Introdução ao pensamento complexo. Porto Alegre: Sulina; 2006.

27. Escrito na Pedra. Jornal Público. 27 fev. 2017;43.

28. Ribeiro JU. Observaçóes de um usuário. O Estado de S. Paulo. 29 mai. 2011.

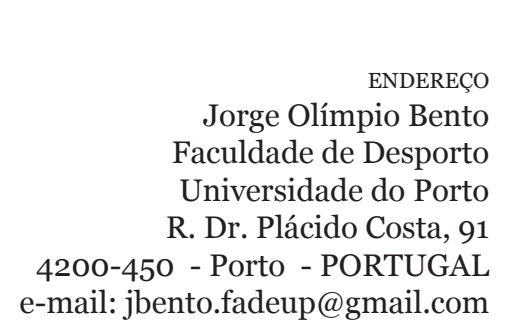

Rev Bras Educ Fís Esporte, (São Paulo). 2017 Ago; 31(N esp):27-49• 49 